Research paper

\title{
Diversity of Pinus pumila-dominated communities on the Kamchatka Peninsula
}

\author{
Jaanus Paal ${ }^{1 *}$, Anton Pesterov ${ }^{2}$ and Valentina Neshataeva ${ }^{2}$
}

Paal, J., Pesterov, A., Neshataeva, V. 2021. Diversity of Pinus pumila-dominated communities on the Kamchatka Peninsula. - Forestry Studies | Metsanduslikud Uurimused 74, 26-57, ISSN 1406-9954. Journal homepage: http:/ / mi.emu.ee/forestry.studies

\begin{abstract}
On the Kamchatka Peninsula, Far East Russia, Pinus pumila-dominated communities occur from sea level up to $1200 \mathrm{~m}$ and geographically from the southern extremity of the peninsula up to the Kamchatka Isthmus and the Koryak Upland. Variation in species composition and abundance in P. pumila stands are determined mainly by the habitat's moisture, soil fertility (expressed as the litter-humus coefficient) and altitude. The fertility level of the habitats has a significant positive impact especially on the abundance of the herb layer species, and to a lesser extent on the cover of the shrub layer. The growth of dwarf-shrubs and lichens is inhibited in habitats with better fertility. In relation to the fertility gradient, the vertical structure of the communities is also changing explicitly; the thickness of snow cover and exposition has a modest effect on the vegetation of P. pumila stands on Kamchatka. The analysed set of 272 relevés were clustered into six community type groups: (i) pure dwarfpine communities, (ii) shrub-rich communities, (iii) dwarf-shrub-rich communities, (iv) herbgrass-rich communities, (v) moss-rich communities and (vi) lichen-rich communities; further 18 community types were established. They have a fairly good correspondence with most of the syntaxa described by previous scholars, but this is not always the case.
\end{abstract}

Key words: altitude, classification, elfin woods, gradient analysis, habitats fertility, moisture conditions, ordination, Siberian dwarf-pine.

Authors' addresses: ${ }^{1}$ Institute of Ecology and Earth Sciences, University of Tartu, Lai 40, 51005 Tartu, Estonia; ${ }^{2}$ Komarov Botanical Institute of the Russian Academy of Sciences, Professor Popov Str. 2, 197376, St. Petersburg, Russia; *e-mail: jaanus.paal@ut.ee

\section{Introduction}

The Siberian dwarf-pine (Pinus pumila (Pall.) Regel) has a peculiar form of growth that differs from trees or shrubs. The stems are prostrate, generally forming a network system buried in the thick litter of fallen needles. In the lowlands, the height of $P$. pumila stands is about $2.5-3.0 \mathrm{~m}$, and in areas of their altitudinal limit only $40-50 \mathrm{~cm}$, while the diameter of the stems is about
12-15 cm. The stems are resistant to low temperature and thick snow cover; they are lodging under the snow and can produce additional roots there. Due to its very wide ecological amplitude (Khomentovsky, 1995), P. pumila has a large geographical distribution and can grow in extremely severe climatic conditions. It occupies vast areas from the Lena River eastward to the coast of the Pacific Ocean, and extends northwards from the Korean Penin-

DOI: $10.2478 /$ fsmu-2021-0003

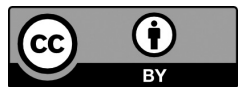

(c) 2021 by the authors. Licensee Estonian University of Life Sciences, Tartu, Estonia. This article is an open access article distributed under the terms and conditions of the Creative Commons Attribution (CC BY) license (http://creativecommons.org/licenses/by/4.0/). 
sula, Honsu Island, Khingan, Sikhote-Alin and Tukuringra up to Southern Chukotka (Tikhomirov, 1949; Kabanov, 1977; Kharkevich, 1984, 1989). In Kamchatskiy Krai, including the Kamchatka Peninsula and northern Koryakia, the total area covered by $P$. pumila stands is about 8.6 million hectares (Grushin, 1961). In Japan, the vegetation belt dominated by $P$. pumila exists in most of the high mountains, being more pronounced on Hokkaido Island (Tatewaki, 1963; Kobayashi, 1967, 1971; Okitsu \& Ito, 1984, 1989; Okitsu, 2002; Yasuda \& Okitsu, 2012).

On the Kamchatka Peninsula, unlike Japan and easten Siberia, P. pumila occupies a very large altitudinal gradient that begins in some places from the sea coast and extends up to the alpine zone (Hultén, 1974; Khomentovsky, 1995; Neshatayeva, 2011); it often occupies dry and nutrient-poor sites, such as stony slopes and sandy deposits of so-called "dry rivers". The latter are temporary mudflows streaming down from the slopes of volcanoes. In the northern regions of Kamchatka and Koryakia, $P$. pumila stands predominate on plains.

The first aim of the present study was to characterize the main ecological gradients that determine the structure of the $P$. pumila stands on the Kamchatka Peninsula. Considering that the classification of these communities is in some aspects an open problem so far, the second aim was to establish the typology of these communities based on a representative data set and a multivariate approach, and to compare established syntaxa with the results of previous researchers.

The nomenclature for vascular plants follows Yakubov \& Chernyagina (2004), for mosses it follows Czernyadjeva (2012), for liverworts Konstantinova et al. (1992), for lichens Santesson et al. (2004).

\section{Materials and Methods}

\section{Study area}

The Kamchatka Peninsula occupies a huge area of $350000 \mathrm{~km}^{2}$ from $50^{\circ} 52^{\prime}$ to $60^{\circ} 52^{\prime}$ north latitude and from $155^{\circ} 34^{\prime}$ to $164^{\circ} 00^{\prime}$ east longitude; the total length of the peninsula from north to south is $1200 \mathrm{~km}$ and the maximum width is $480 \mathrm{~km}$. The peninsula has a folded volcanic topography with mountain ranges reaching 2500-3000 m a.s.l., separated by deep meridional depressions and lowlands. Nowadays, 30 active volcanoes are recorded on the peninsula, the highest of which is the Kluchevskaya Sopka - $4835 \mathrm{~m}$ a.s.l. Volcanic eruptions of low magnitude, with the ejection of 1-10 million $\mathrm{m}^{3}$ of indigenous rock take place almost every year, producing a significant amount of volcanic ash, scoria and lava. Eruptions of high magnitude occur almost every 400 years, resulting in regional catastrophes (Braitseva et al., 1997; Gusev et al., 2003).

Kamchatka's climate is quite cold and humid; the sum of active temperatures above $10^{\circ} \mathrm{C}$ does not exceed 1200 and the duration of the vegetation period is about 100 days. The average temperature in July is $+15^{\circ} \mathrm{C}$, and in February it is $-15-(-20)^{\circ} \mathrm{C}$. The annual precipitation varies from 350 $\mathrm{mm}$ in the central valley to $1200 \mathrm{~mm}$ on the eastern coast. The average thickness of the snow cover is about $100 \mathrm{~cm}$ (Kondratyuk, 1974).

The soil cover of Kamchatka is mainly formed by specific types of volcanic soils (Andosols) (Sokolov, 1973; Zakharikhina \& Litvinenko, 2011). They are characterized by several layers of volcanic tephra alternating with organic horizons.

\section{Field data}

Field data were collected in all districts of the Kamchatka Peninsula (Figure 1) where P. pumila stands are present. Vegetation analyses were carried out in the course of 1974-2008, but always in the same vegetation period, from the second half of July to 
the end of August. In every sample area the sample plots of $10 \times 10 \mathrm{~m}$ were established along the downslope transects with an interval of $100 \mathrm{~m}$ through the whole P. pumila belt. In that way the sample plots covered all P. pumila communities presented in the considered sample area. The geographic coordinates and altitude were registered using a GPS device; exposition and inclinisation were estimated with a compass and declinometer.

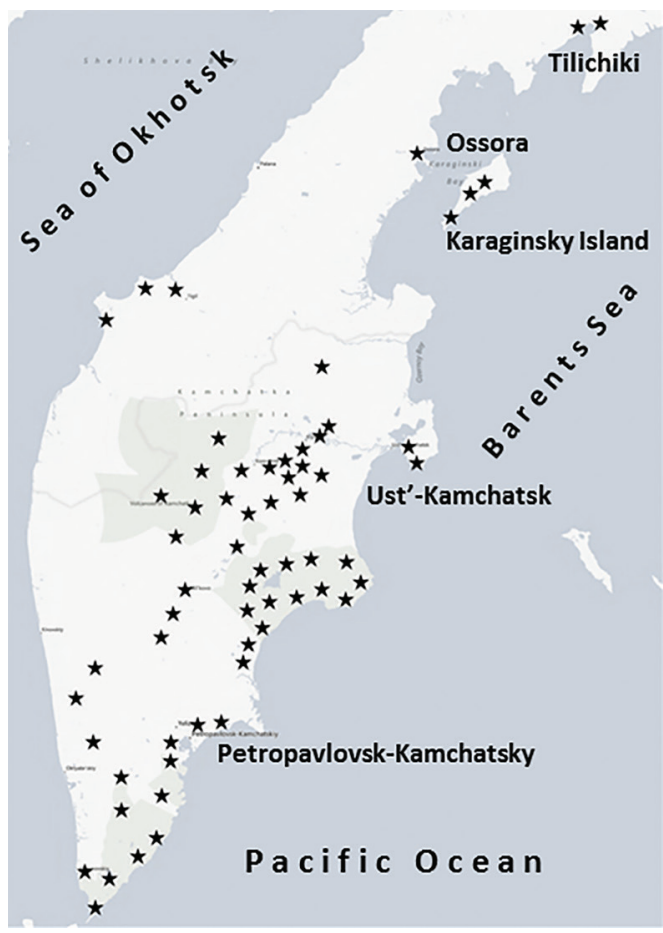

Figure 1. Location of sample areas on the Kamchatka Peninsula.

The total cover percentage of $P$. pumila and all lower layers was estimated visually, as well as the cover of every species in the field and bottom layers.

Moisture conditions were evaluated according to Kachinsky (1970) and Mazirov et al. (2012) through the first four steps of their five-step scale: 1 - dry soil; brings forth dust, the hand does not feel coldness, no feeling when touching moisture, 2 fresh soil; coldness in the hand, forms no dust, becomes a little lighter by drying, 3 moist soil; moistens the filter paper, when drying it brightens remarkably, retains the shape given by the hand, moisture is clearly felt by touching, 4 - wet soil; when compressed it turns into a dough-like mass, wets hand but does not trickle between the fingers.

We used the ratio of the thickness of the humus horizon (A) to the thickness of the litter $(\mathrm{O})$ or peaty litter $(\mathrm{Oa})$ horizon as a proxy for soil fertility (Chertov, 1981); in the case of the absence of the humus horizon, value 1 was used in the calculation. In soil studies of the Russian Far East, this ratio is called as the "litter-humus coefficient" (Sapozhnikov, 1993). A consistent correlation between the soil real fertility and the value of the litter-humus coefficient was affirmed by statistical models (Chertov, 1981; Sapozhnikov, 1993; Komarova, 2004). According to the litter-humus coefficient, for oligotrophic soils the value of $\mathrm{A} / \mathrm{O}$ or $\mathrm{A} / \mathrm{Oa}$ is in limits of $0.00-0.10$, for meso-oligotrophic soils $0.91-1.10$ and for mesotrophic soils $>1.10$. Since there were no limestone outcrops (carbonate rocks) in Kamchatka, we also took into account the granulometric composition of the soils. The poorest (oligotrophic) soils are rocky, gravelly, or sandy; medium-rich soils (meso-oligotrophic and mesotrophic) are sandy loams or loamy sands; relatively richer (meso-eutrophic) soils are loams. Additionally, the presence of the peat horizon $(\mathrm{H})$, indicating soil oligotrophy (due to the acid reaction of sphagnum peat) and the habitat drainage conditions were taken into account. The soil fertility was the lowest in dry habitats, as well as in poorly drained habitats; the soils in normally drained habitats were relatively rich.

The complete data set analysed in the current study included 272 relevés.

\section{Data processing}

To reduce the information noise in data processing, species that appear in the data fewer than three times were removed prior 
to multivariate analyses, except by calculating the average number of species and the evenness coefficients for community types. To assess the insolation effect, the exposition bearings (compass points) were transformed into continuous variables as follows: $\mathrm{N}-0^{\circ}, \mathrm{NW}$ and $\mathrm{NE}-45^{\circ}, \mathrm{W}$ and $\mathrm{E}-90^{\circ}, \mathrm{SW}$ and $\mathrm{SE}-135^{\circ}, \mathrm{S}-180^{\circ}$, plain $-250^{\circ}$.

The mutual relationship of all environmental variables was evaluated by Spearman rank-order correlations (StatSoft Inc., 2005).

The main gradients of the species data were examined using the Detrended Correspondence Analysis DCA (Jongman et al., 1995) implemented in the PC-ORD software package ver. 7 (McCune \& Mefford, 2016); the rescaling threshold was 0.1 and the number of segments was 26 . The total cover of shrubs, herbs, dwarf-shrubs, mosses and lichens were also considered as environmental factors. The relationship between species abundance and environmental variables was depicted using ordination biplots. The strength of the environmental variables with ordination axes was evaluated by means of correlation coefficients between the axes scores and the variable values.

Multiple regression analyses were used to study the impact of environmental characteristics (predictor variables) variables to the variables of the vegetation structure; the models were built up by forward stepwise entry of variables (StatSoft Inc., 2005). The goal of the variables selection is to achieve a balance between simplicity (as few predictor variables as possible) and fit (as many predictors as needed) (Lancaster, 1999). The forward selection begins with an empty model and predictor variables are added one at a time beginning with the predictor with the highest correlation with the dependent variable. Variables of greater importance are entered first and the process is continued until no more predictor variables are admitted to the model and no more steps are repeated.
In cluster analysis, the chord distance and the flexible $\beta$ algorithm $(\beta=-0.6)$ were applied (McCune \& Grace, 2002). Differences in the species composition between clusters were tested using a nonparametric multi-response permutation procedure (MRPP) (Mielke, 1984). To characterize the internal diversity of the clusters, the mean number of species and the evenness coefficient were used (Pielou, 1977).

The indicator values of the species in clusters were calculated using the Dufrêne and Legendre (1997) method included in the PC-ORD software package (McCune \& Grace, 2002). The statistical significance of the obtained indicator values was evaluated by the Monte Carlo permutation test (4999 runs).

The difference between the mean values of the environmental variables in the established community types was tested by means of the univariate ANOVA and Fischer LSD post-hoc test; the difference in the median values for exposition, moisture and fertility estimations was verified by the Kruskal-Wallis ANOVA and Duncan's test (StatSoft Inc., 2005).

The classification of the geographical floristic elements (geoelements) of the vascular species proposed by Hultén (1968, 1974) and Hultén \& Fries (1986) follows the adapted version for Far East elaborated by Qian et al. (2003) and Krestov (2003); the classification of vascular plant species according to their longitudinal and latitudinal areal types sensu Meusel et al. (1965) and Hundt (1985) follows Yurtsev (1994).

\section{Results}

The total number of vascular plant species identified in the current data set was 180 , that of bryophytes was 56 , and that of lichens was 78 (60 species of epiphytic lichens are not included in the current analysis). Phytogeographically, 130 of the 271 vascular plant species represented Euro-Siberian floristic elements (geoelements), of 
which 63 had circumpolar, 34 Eurasian, 21 continental Eurasian, 15 European and 7 subatlantic European distribution. The largest fraction of the species belonged to the mountain-tundra (58\%) and forest $(42 \%)$. Considering the temperature, the species of the mesothermal climate prevailed $(65 \%)$, the proportion of microthermal species was remarkably lower (35\%).

According to the longitudinal distribution of vascular plant species, the circumboreal species had the largest fraction (39\%), followed by eastern Asiatic (29\%), circumpolar $(17 \%)$ and Asiatic-American (15\%) species. The presence of Asiatic-American species in the subordinate layers is a regional peculiarity of the P. pumila stands of the Kamtchatka Peninsula and the Koryak Upland. According to the latitudinal distribution, the most important were the boreal $(55 \%)$, arcto-alpine $(25 \%)$ and hypoarctic species $(9 \%)$.

Considering the moisture gradient, psychro-mesophytes (36\%) and eu-mesophytes $(33 \%)$ had the leading position, confirming in general a psychrophilic and subalpine character of $P$. pumila communities.

The variation of the content and abundance of species in P. pumila stands on the Kamchatka Peninsula is primarily determined by the habitat fertility level; its correlation coefficient with the first ordination axis is 0.605 (Figure $2 \mathrm{~A}, \mathrm{~B}$, Table 1 ). The impact of the altitude and moisture level are remarkably weaker according to the ordination analysis: the correlation coefficient of the altidude with the first ordination axis is -0.346 and with the second axis 0.324; the moisture level has the highest correlation $(-0.455)$ with the third ordination axis (Figure $2 \mathrm{~A}, \mathrm{~B}$, Table 1 ).

Ordination biplots (Figure 2 A,B) also visualise the mutual relationships between the considered environmental and vegetation structure variables. A positive relationship between the habitat fertility level and the total cover of the herb layer is obvious; the total cover of the dwarf-shrubs and that of the lichen layer have a negative relation
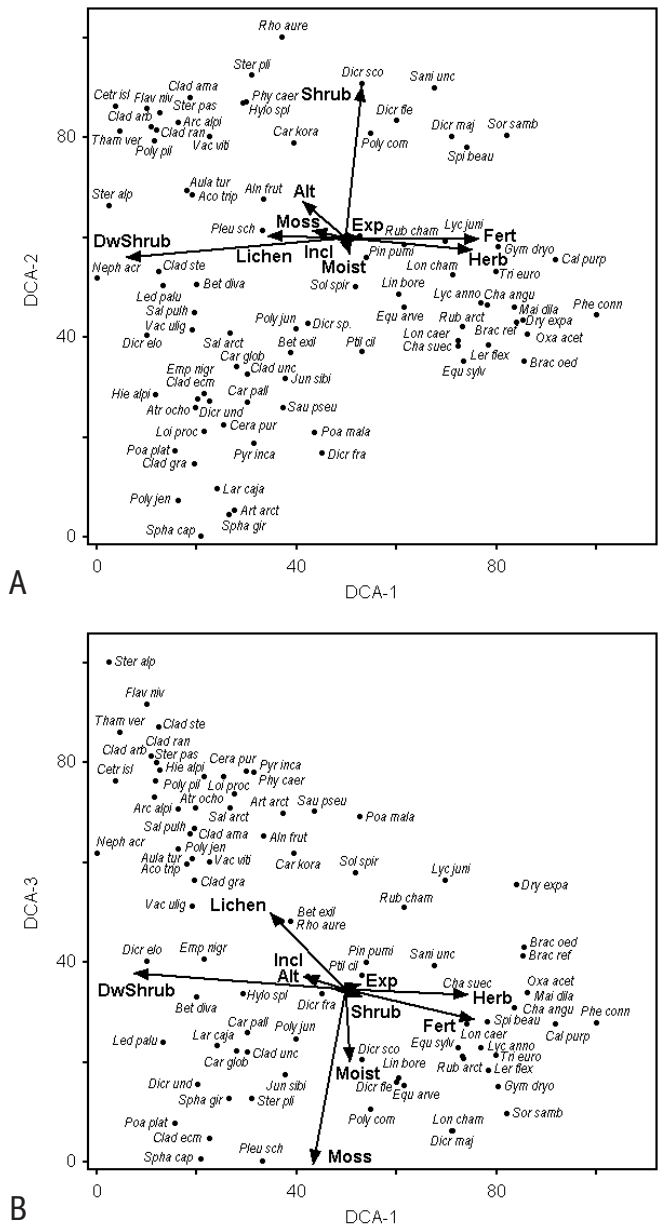

Figure 2. Species and environmental variables ordination biplot by the DCA axes 1 and $2(A)$, and axes 2 and 3 (B). Notations: Fert, Moist - habitat fertility and moisture level, Incl - habitat inclination, Alt - altitude, Exp - exposition; Shrub, Herb, DwShrub, Moss and Lichen - total cover of shrubs, herbs, dwarf-shrubs, mosses and lichens, respectively; Ppum - cover of Pinus pumila. The full names of the species are presented in Appendix 1.

with the habitat fertility level. The total cover of the moss layer increases, while the total cover of the lichen layer decreases along with the habitat moisture gradient. Dwarf-shrubs and lichens are modestly favoured at a higher altitude, but the herb layer is remarkably reduced. 
Table 1. Correlation of environmental variables with DCA ordination axes. Notations: $r$ - Pearson correlation coefficient, $\tau$ - Kendall rank order correlation coefficient; other notations as in Figure 2.

\begin{tabular}{lccccccccc}
\hline Variable & \multicolumn{3}{c}{ Axis 1 } & \multicolumn{3}{c}{ Axis 2 } & \multicolumn{3}{c}{ Axis 3 } \\
\cline { 2 - 10 } & \multicolumn{1}{c}{$r$} & $\mathrm{r}^{2}$ & $\tau$ & $\mathrm{r}$ & $\mathrm{r}^{2}$ & $\tau$ & $\mathrm{r}$ & $\mathrm{r}^{2}$ & $\tau$ \\
\cline { 2 - 9 } & 0.107 & 0.012 & 0.124 & -0.223 & 0.050 & -0.136 & -0.455 & 0.207 & -0.385 \\
Moist & 0.605 & 0.366 & 0.490 & -0.067 & 0.004 & -0.051 & -0.294 & 0.087 & -0.196 \\
Ext & 0.203 & 0.041 & 0.160 & -0.013 & 0.000 & 0.005 & -0.128 & 0.016 & 0.067 \\
Incl & -0.188 & 0.035 & -0.159 & 0.014 & 0.000 & 0.019 & 0.046 & 0.002 & 0.036 \\
Alt & -0.346 & 0.119 & -0.245 & 0.324 & 0.105 & 0.204 & 0.200 & 0.040 & 0.108 \\
Shrub & 0.218 & 0.047 & 0.187 & 0.649 & 0.421 & 0.405 & -0.143 & 0.020 & -0.122 \\
DwShrub & 0.593 & 0.352 & 0.423 & -0.184 & 0.034 & -0.146 & -0.135 & 0.018 & -0.131 \\
Herb & -0.778 & 0.605 & -0.663 & -0.234 & 0055 & -0.116 & 0.214 & 0.046 & 0.149 \\
Moss & -0.306 & 0.094 & -0.211 & 0.151 & 0.023 & 0.166 & -0.708 & 0.501 & -0.524 \\
Lichen & -0.463 & 0.215 & -0.461 & 0.084 & 0.007 & 0.004 & 0.470 & 0.221 & 0.207 \\
\hline
\end{tabular}

The results of the ordination analysis were statistically specified by the multiple regression analyses. It appeared that the total number of species is suppressed by the increasing cover of $P$. pumila and shrub layer, as well as by the higher moisture level (Table 2); the higher fertility and altitude of habitats support the species diversity. Still, the regression model includes also squared terms of fertility and moisture, indicating a non-linear impact of these factors to the total number of species.

The total cover of the shrub layer (excluding $P$. pumila) is enhanced by the habitats' higher altitude and fertility but, again, the significance of squared fertility in the regression model refers to a non-linear relationship of that factor with the shrub layer total cover (Table 2). Somewhat surprisingly, we did not find any regressor having a significant influence on the P. pumila total cover.

The dwarf-shrubs are favoured on higher altitudes, but the higher fertility of habitats, similar to the higher cover of $P$. pumila and the shrub layer decreases their total cover (Table 2).
The herb layer has a higher cover on more fertile localities, a negative impact on which have the higher altitude and sharper inclination, the total cover of P. pumila and dwarf shrubs (Table 2).

The total cover of mosses is enhanced by the habitats' moisture, whereas the higher cover of herbs and habitats' exposition to southern directions or their location on plains has a negative impact on the moss layer development (Table 2).

The lichens have the highest cover in highlands, while in moist and relatively fertile habitats they are suppressed. Nevertheless, the significant terms of squared fertility and moisture in the regression model point on the non-linearity of these relationships. The regression model proves also the negative impact of $P$. pumila and the shrub layer cover on lichens.

The analysed set of 272 relevés was classified into six community type groups, quite distinctly separated on an ordination biplot (Figure 3), and further divided into 18 clusters, i.e. community types. In every community type, different species dominate (Appendix 1) and all types have their 
Table 2. Environmental variables affecting the total number of species and projective cover of different vegetation layers according to the multiple regression analyses by stepwise entry of variables. Notations: $\beta$ - standardized regression coefficient, $\mathrm{SE}_{\beta}$ - its standard error, $\mathrm{B}$ - unstandardized regression coefficient (slope), $\mathrm{SE}_{\mathrm{B}}$ - its standard error, $\mathrm{t}$ - value of t-criterion, $p$ - significance level, Mu $R^{2}$ - multiple $R^{2}, A d R^{2}$ - adjusted $R^{2}, F$ - value of F-criterion. Other notations as in Figure 2.

\begin{tabular}{|c|c|c|c|c|c|c|c|c|c|c|}
\hline \multirow{2}{*}{ Variable } & \multirow{2}{*}{$\beta$} & \multirow{2}{*}{$\mathrm{SE}_{\beta}$} & \multirow{2}{*}{ B } & \multirow{2}{*}{$\mathrm{SE}_{\mathrm{B}}$} & \multirow{2}{*}{$\mathrm{t}$} & \multirow{2}{*}{$\mathrm{p}$} & \multicolumn{4}{|c|}{ Summary statistics } \\
\hline & & & & & & & $\mathrm{Mu} \mathrm{R}^{2}$ & $\mathrm{Ad} \mathrm{R}^{2}$ & $\mathrm{~F}$ & $\mathrm{p}$ \\
\hline \multicolumn{11}{|c|}{ Total number of species } \\
\hline Intercept & & & 14.68 & 2.073 & 7.08 & $<0.001$ & 0.156 & 0.134 & 7.23 & $<0.001$ \\
\hline Ppum & -0.22 & 0.057 & -0.06 & 0.014 & -3.84 & $<0.001$ & & & & \\
\hline Moist $^{2}$ & 1.29 & 0.370 & 1.42 & 0.407 & 3.50 & 0.001 & & & & \\
\hline Shrub & -0.17 & 0.060 & -0.04 & 0.013 & -2.73 & 0.006 & & & & \\
\hline Alt & 0.14 & 0.062 & 0.01 & 0.001 & 2.21 & 0.025 & & & & \\
\hline Moist & -1.22 & 0.382 & -6.816 & 2.125 & -3.22 & 0.002 & & & & \\
\hline Fert & 1.26 & 0.355 & 6.23 & 1.750 & 3.56 & $<0.001$ & & & & \\
\hline Fert $^{2}$ & -1.10 & 0.332 & -1.11 & 0.337 & -3.30 & 0.001 & & & & \\
\hline \multicolumn{11}{|c|}{ Total cover of shrubs, square root transformed } \\
\hline Intercept & & & -1.32 & 0.912 & -1.44 & 0.150 & 0.136 & 0.126 & 14.55 & $<0.001$ \\
\hline Alt & 0.29 & 0.058 & 0.01 & 0.000 & 4.92 & $<0.001$ & & & & \\
\hline Fert & 0.93 & 0.282 & 2.61 & 0.795 & 3.28 & 0.001 & & & & \\
\hline Fert $^{2}$ & -0.74 & 0.284 & -0.43 & 0.165 & -2.59 & 0.010 & & & & \\
\hline \multicolumn{11}{|c|}{ Total cover of dwarf shrubs, square root transformed } \\
\hline Intercept & & & 8.39 & 0.745 & 11.26 & $<0.001$ & 0.344 & 0.335 & 36.38 & $<0.001$ \\
\hline Fert & -0.35 & 0.051 & -1.20 & 0.173 & -6.93 & 0.001 & & & & \\
\hline Ppum & -0.27 & 0.049 & -0.05 & 0.009 & -5.49 & $<0.001$ & & & & \\
\hline Shrub & -0.23 & 0.052 & -0.04 & 0.017 & -4.42 & $<0.001$ & & & & \\
\hline Alt & 0.23 & 0.053 & 0.01 & 0.001 & 4.32 & $<0.001$ & & & & \\
\hline \multicolumn{11}{|c|}{ Total cover of herbs, square root transformed } \\
\hline Intercept & & & 3.32 & 0.663 & 5.00 & $<0.001$ & 0.502 & 0.493 & 55.59 & $<0.001$ \\
\hline Fert & 0.44 & 0.047 & 1.28 & 0.137 & 9.32 & $<0.001$ & & & & \\
\hline Alt & -0.34 & 0.045 & -0.01 & 0.000 & -7.60 & $<0.001$ & & & & \\
\hline Ppum & -0.18 & 0.045 & -0.03 & 0.007 & -3.97 & $<0.001$ & & & & \\
\hline DwShrub & -0.16 & 0.049 & -0.02 & 0.006 & -3.22 & 0.001 & & & & \\
\hline Incl & -0.10 & 0.044 & -0.02 & 0.008 & -2.38 & 0.018 & & & & \\
\hline \multicolumn{11}{|c|}{ Total cover of mosses, square root transformed } \\
\hline Intercept & & & 2.55 & 0.625 & 4.08 & $<0.001$ & 0.238 & 0.230 & 28.96 & $<0.001$ \\
\hline Moist & 0.41 & 0.053 & 1.70 & 0.222 & 7.67 & $<0.001$ & & & & \\
\hline Herb & -0.22 & 0.053 & -0.04 & 0.008 & -4.14 & $<0.001$ & & & & \\
\hline Exp & -0.15 & 0.053 & -0.01 & 0.003 & -2.87 & 0.004 & & & & \\
\hline
\end{tabular}


Table 2 continues

\begin{tabular}{|c|c|c|c|c|c|c|c|c|c|c|}
\hline \multirow{2}{*}{ Variable } & \multirow{2}{*}{$\beta$} & \multirow{2}{*}{$\mathrm{SE}_{\beta}$} & \multirow{2}{*}{ B } & \multirow{2}{*}{$\mathrm{SE}_{\mathrm{B}}$} & \multirow{2}{*}{$\mathrm{t}$} & \multirow{2}{*}{$\mathrm{p}$} & \multicolumn{4}{|c|}{ Summary statistics } \\
\hline & & & & & & & $\mathrm{Mu} \mathrm{R}^{2}$ & $\mathrm{Ad} \mathrm{R}^{2}$ & $\mathrm{~F}$ & $\mathrm{p}$ \\
\hline \multicolumn{11}{|c|}{ Total cover of lichens, square root transformed } \\
\hline Intercept & & & 10.34 & 0.806 & 12.83 & $<0.001$ & 0.504 & 0.492 & 39.81 & $<0.001$ \\
\hline Fert & -0.79 & 0.272 & -1.97 & 0.682 & -2.89 & 0.004 & & & & \\
\hline Moist & -1.27 & 0.294 & -3.58 & 0.831 & -4.31 & $<0.001$ & & & & \\
\hline Moist $^{2}$ & 1.01 & 0.284 & 0.57 & 0.159 & 3.57 & $<0.001$ & & & & \\
\hline Ppum & -0.20 & 0.043 & -0.03 & 0.006 & -4.65 & $<0.001$ & & & & \\
\hline Alt & 0.19 & 0.047 & $<0.01$ & 0.000 & 4.08 & $<0.001$ & & & & \\
\hline Shrub & -0.16 & 0.047 & -0.14 & 0.041 & -3.44 & 0.001 & & & & \\
\hline Fert $^{2}$ & 0.56 & 0.255 & 0.29 & 0.131 & 2.18 & 0.030 & & & & \\
\hline
\end{tabular}

own significant indicator species (Appendix 2). The MRPP test confirmed the objectivity of community types: even taking into account the Bonferroni correction for multiple comparisons, all established types had a significantly different $(\mathrm{p}<0.001)$ species composition. In the following text, the established community types are labeled by their dominant and/or indicator species.

(i) Group of pure dwarf-pine communities: Among the communities belonging to this group, the other layers besides P. pumila are very poorly developed or completely absent. The average number of species in these communities is approximately 10 (Table 3). This group includes only the $P$. pumila pure type ( $1^{\text {st }}$ cluster $)$ with sparse and sporadic specimens of grasses, herbs and/or dwarf-shrubs (Appendix 1). The very low evenness of these communities is remarkable (Table 3), indicating a great disparity between the abundance of species (P. pumila versus other species). In these communities, only P. pumila is a significant indicator species (Appendix 2). These communities are situated on moderate slopes having medium moisture and fertility level (Table 3); they are distributed throughout the peninsula and can be encountered at different altitudes. By the floristic composition within this type, two subtypes could be distinguished: for the first subtype the occurrence of boreal low herbs - Linnaea

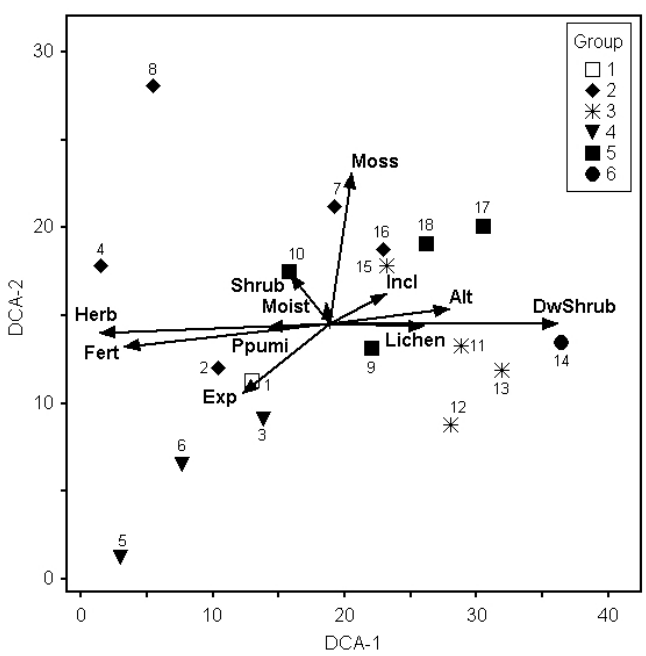

Figure 3. Community type centroids and environmental variables ordination biplot. Notations: group 1 - pure dwarf-pine communities, group 2 shrub-rich communities, group 3 dwarf-shrub-rich communities, group 4 - herb-grass-rich communities, group 5 - moss-rich communities, group 6 - lichen-rich communities; other notations as in Figure 2.

borealis, Trientalis europaea, Lycopodium annotinum, Maianthemum dilatatum, Equisetum sylvaticum and mesophytic mosses Dicranum scoparium, D. majus, D. fuscescens are characteristic; in communities of the second subtype of dwarf-shrubs - Vaccinium minus, V. uliginosum, Ledum decumbens and Empetrum nigrum are present. 


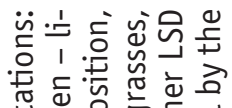

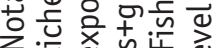
可过

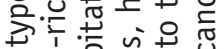

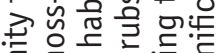
吉

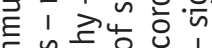
है

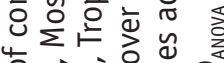

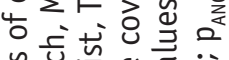

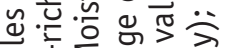

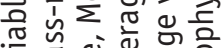

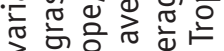

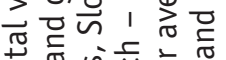

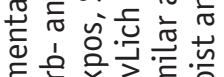

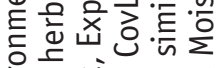

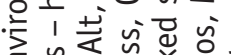

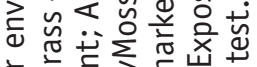

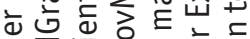

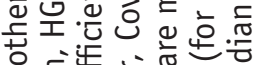

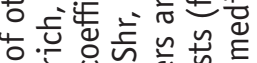
प.

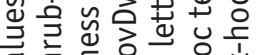

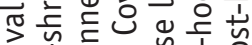

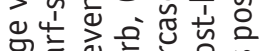

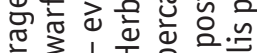

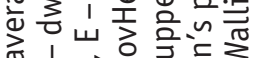
む1 v

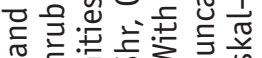

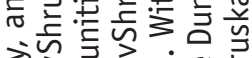

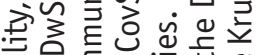

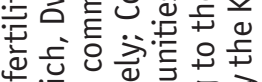

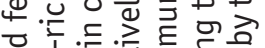

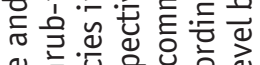

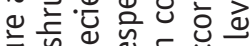

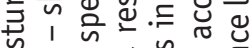

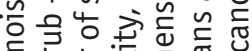

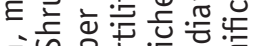
¿

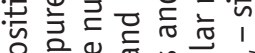

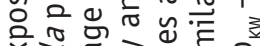

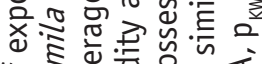

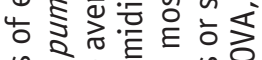

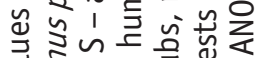

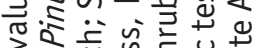

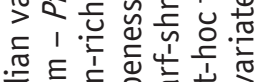

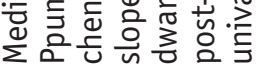

mi

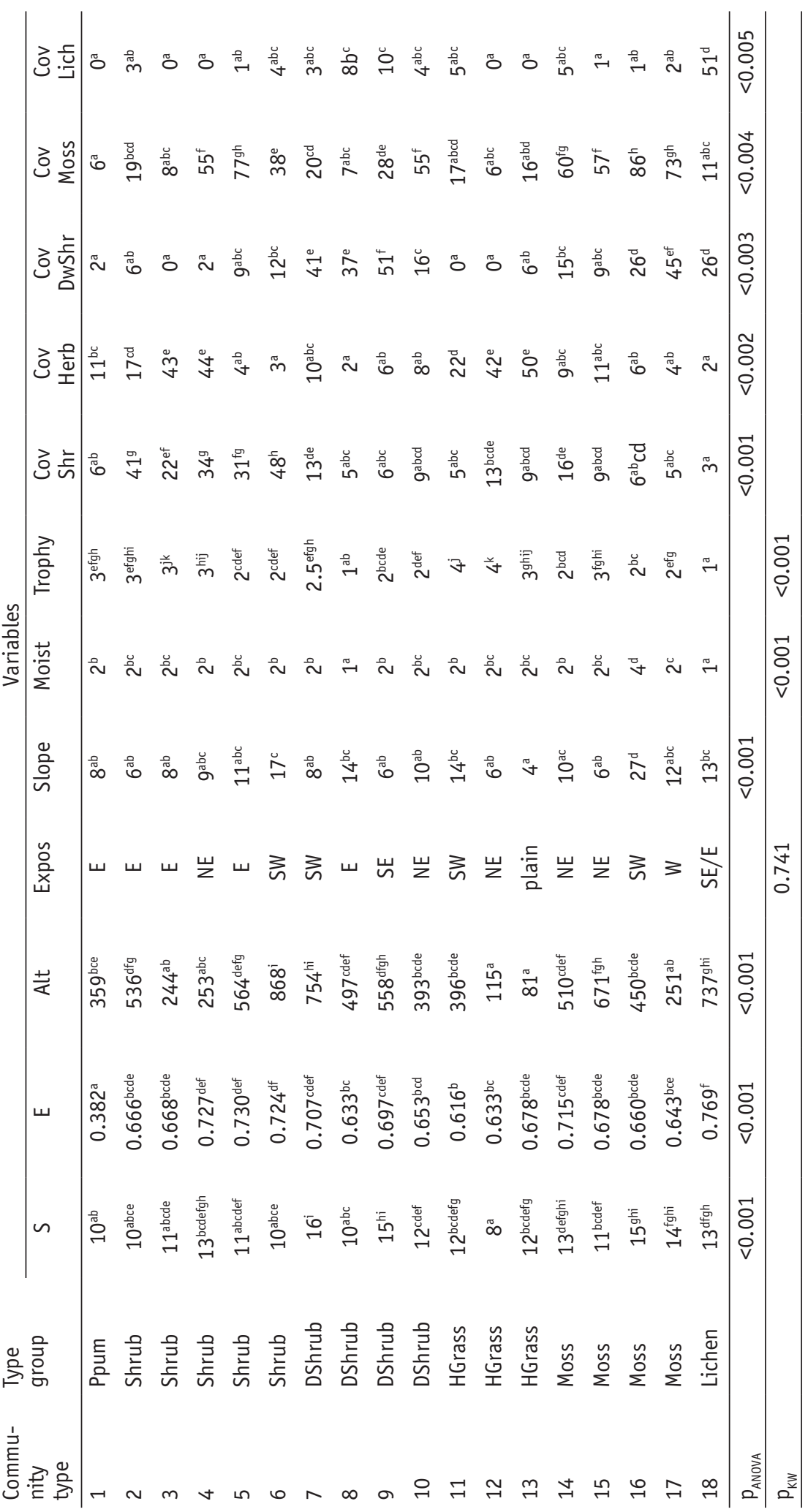


(ii) Group of shrub-rich communities: In these communities, besides P. pumila, shrubs such as Spiraea beauverdiana, Sorbus sambucifolia and/or Rhododendron aureum have a dominant position; the average number of species is 10-13 (Table 3). This group includes communities of five types:

P. pumila-Spiraea beauverdiana-Calamagrostis langsdorffii type ( $2^{\text {nd }}$ cluster). These communities are characterized by the predominance of Spiraea beauverdiana in the shrub layer and the high abundance of $\mathrm{Cal}$ amagrostis langsdorffii in the field layer. In the scarse bottom layer, Plagiomnium cuspidatum is the indicator species (Appendix 2), while Dicranum scoparium, Polytrichum commune and Pleurozium schreberi are admixed (Appendix 1). These communities develop on mesic mesotrophic sites in the upper-middle part of the subalpine zone, occurring throughout the peninsula.

P. pumila-Sorbus sambucifolia-Maianthemum dilatatum type ( $3^{\text {rd }}$ cluster). For these communities low herbs (Maianthemum dilatatum, Oxalis acetosella) and quite abundant ferns (Phegopteris connectilis, Dryopteris expansa) are characteristic (Appendix 2). Sorbus sambucifolia prevails in the shrub layer. The bottom layer is tenuous, but Brachythecium reflexum and Sanionia uncinata are common (Appendix 1). These communities are located in rich mesic sites at low altitudes in the southern and south-eastern parts of the peninsula.

P. pumila-Sorbus sambucifolia-Gymnocarpium dryopteris type ( $4^{\text {th }}$ cluster) is characterized by the relatively high cover of boreal low herbs: Linnaea borealis, Gymnocarpium dryopteris, Chamaepericlymenum suecicum and Lycopodium annotinum; Sorbus sambucifolia dominates in the shrub layer. In the bottom layer, Pleurozium schreberi is abundant, and Polytrichum commune, Dicranum majus, D. scoparium and Sanionia uncinata are also common (Appendix 1). These communities develop on rich mesic sites at low altitudes, occurring on maritime terraces of the Pacific coast of south-eastern Kamchatka.
In the communities of P. pumila-Rhododendron aureum-Polytrichum commune type ( $5^{\text {th }}$ cluster), the predominance of Rhododendron aureum in the shrub layer and the high cover of Polytrichum commune in the bottom layer are specific (Appendix 1). Some other species of dwarf-shrubs (Vaccinium vitis-idaea, Ledum palustre) and mosses (Pleurozium schreberi, Dicranum scoparium, Sphagnum girgensohnii) are common. Communities occur in poor mesic sites in the upper-middle part of the subalpine zone; they are mainly distributed in eastern and central Kamchatka and on Karaginsky Island.

For the communities of $P$. pumila-Rhododendron aureum-Dicranum scoparium type ( $6^{\text {th }}$ cluster), the low $(40-50 \mathrm{~cm})$ shrub layer formed by Rhododendron aureum, covering about $40 \%$ is characteristic. Instead of Polytrichum commune, Dicranum scoparium and Pleurozium schreberi prevailed in the bottom layer (Appendix 1). The communities were found in mesic mesotrophic sites at the upper limit of the subalpine belt, that is, $800-900 \mathrm{~m}$ a.s.1.. They occur in the eastern, central and south-eastern parts of Kamchatka. The average evenness coefficient of the latter three community types was relatively high (Table 3 ), denoting a rather equal abundance of species in the respective communities.

(iii) Group of dwarf-shrub-rich communities: In the communities of this group, the projective cover of $P$. pumila layer is comparatively low (about 50\%), which promotes the growth of light-demanding dwarf-shrubs - Vaccinium uliginosum, $V$. vitis-idaea, Empetrum sibiricum, Ledum palustre, Loiseleuria procumbens and Arctous alpine. In the moss layer, Pleurozium shreberi is the most abundant species; among the lichens, Cladonia rangiferina and C. gracilis are common. This group includes communities of four types.

P. pumila-Vaccinium uliginosum-Ceratodon purpureus type ( $7^{\text {th }}$ cluster) is characterized by the predominance of Vaccinium uliginosum and the presence of Saussurea 
pseudo-tilesii, Pyrola incarnata, Atragene ochotensis and Carex koraginensis in the field layer. In the scattered shrub layer, Salix pulchra, S. hastata, Ribes triste and sometimes Rhododendron aureum can be come across (Appendix 1). In the bottom layer, the pioneer mosses Ceratodon purpureus, Racomitrium lanuginosum and Polytrichum juniperinum are indicative (Appendix 2). The average number of species in the communities is releatively high, at 16 (Table 3 ). These communities are distributed on the high mountain plateaus around active volcanoes in central and eastern Kamchatka, where they have developed on Andosols of dry mesotrophic sites in volcanic ash and scoria deposits. Communites of this type probably represent a successional stage of subalpine vegetation that recovers after damage caused by volcanic eruptions.

In the communities of $P$. pumila-Vaccinium vitis-idaea-Stereocaulon paschale type ( $8^{\text {th }}$ cluster), Vaccinium vitis-idaea is prevalent in the dwarf-shrub layer, and Empetrum nigrum and Vaccinium uliginosum are also common (Appendix 1). In the bottom layer, there are numerous bryophytes, but with relatively low abundance; the most remarkable among them are Polytrichum commune and Dicranum fuscescens. Rather abundantly grow lichens Stereocaulon paschale and Cladonia rangiferina. These communities are located in relatively poor and dry sites on steep slopes at upper middle-altitudes (450-600 $\mathrm{m}$ a.s.1.) in the mountains of the Sredinny Range, Ganalsky Range, Valaginsky Range and in the northern part of the peninsula.

In the communities of P. pumila-Empetrum nigrum-Cladonia gracilis type ( $9^{\text {th }}$ cluster), Empetrum nigrum and Vaccinium uliginosum predominate in the dwarf-shrub layer, and Pleurozium schreberi and Cladonia gracilis are frequent in the bottom layer (Appendix 1 and 2). The communities are comparatively rich in species, including about 15 species (Table 3). They develop in mesic and mesotrophic sites at an altitudinal range of $500-700 \mathrm{~m}$, i.e. in the middle part of the subalpine zone, and are widely distributed throughout the peninsula.

In the dwarf-shrub layer of P. pumila-Ledum palustre-Sphagnum lenense type communities (10 ${ }^{\text {th }}$ cluster), Ledum palustre is the most abundant species, but Vaccinium vitis-idaea and $V$. uliginosum are also present (Appendix 1). In the bottom layer, Pleurozium schreberi, Polytrichum commune and Sphagnum lenense are common, the latter being a significant indicator species (Appendix 2). These communities occupy relatively poor and wet sites. On Kamchatka peninsula, communities of this type are very rare, occurring only in the northern part of the peninsula, but they are very common on Cryosols of permafrost areas in the Koryak region and on Karaginsky Island.

(iv) Group of herb-grass-rich communities: This group comprises three community types:

P. pumila-Lerchenfeldia flexuosa-Chamerion angustifolium type ( $11^{\text {th }}$ cluster) communities are characterized by a comparatively large number of herb species and abundant grasses (Calamagrostis langsdorffii, Lerchenfeldia flexuosa and Deschampsia borealis). The sedge Carex pallida and herbs, such as Chamerion angustifolium, Thalictrum minus, Linnaea borealis, etc. are also common; dwarf-shrubs are almost lacking. These communities are located in mesic and meso-eutrophic habitats in the middle part of the subalpine zone; their distribution is confined mainly to the humid coastal areas of the peninsula.

In the communities of $P$. pumila-Calamagrostis langsdorffii-Rubus chamaemorus type (12 ${ }^{\text {th }}$ cluster), Calamagrostis langsdorffii has the highest dominance (Appendix 1) and indicator value (Appendix 2). Phegopteris connectilis and Rubus chamaemorus are relatively abundant, as well. Dwarfshrubs and lichens are completely lacking, thus the average number of species in the communities is the lowest ( 8 species) among the established types (Table 2). In the sparse shrub layer, Spiraea beauverdiana 
is common. The communities have developed in the most nutrient-rich and rather wet habitats at the lower bound (50-200 m a.s.l.) of the P. pumila stands; they occur on Karaginsky Island and on the Kamchatka Isthmus.

In the communities of P. pumila-Chamaepericlymenum suecicum-Equisetum sylvaticum type ( $13^{\text {th }}$ cluster), the title species are the most abundant in the field layer (Appendix 1), but also Rubus chamaemorus, Carex globularis and Betula exilis are significant indicator species (Appendix 2). Dwarf shrubs are presented, but with low abundance. These communities occupy mesotrophic moist sites at low altitudes; they occur on peaty permafrost soils (Cryosols) in the peripheral parts of raised bogs and palsas; their distribution is limited to the north and north-east of Kamchatka.

(v) Group of moss-rich communities: In these communities, the total cover of the moss layer can be as high as $80 \%$. This group embraces communities of four types:

In the communities of $P$. pumila-Dicranum spp.-Mnium thomsonii type $\left(14^{\text {th }}\right.$ cluster), a high abundance of Dicranum spp., Pleurozium schreberi and Polytrichum commune is inherent in the bottom layer; Spiraea beauverdiana occurs in the shrub layer, while Vaccinium vitis-idaea is quite abundant in the field layer (Appendix 1). The communities are situated in Leptosols of poor mesic sites on stony slopes of ancient lava flows and rocky outcrops where Mnium thomsonii is very common. They are distributed in the southern, central and eastern Kamchatka.

In communities of $P$. pumila-Dicranum spp.-Polytrichum commune type $\left(15^{\text {th }}\right.$ cluster), Polytrichum commune, Pleurozium schreberi, Sanionia uncinata and some Dicranum species (D. scoparium, D. majus, and D. flexicaule are constant and abundant (Appendix 1); a significant indicator species is D. flexicaule (Appendix 2). Due to the high cover $(80 \%)$ of $P$. pumila, there is virtually a lack of herbs and lichens. The respec- tive communities are situated in the mesic and mesotrophic habitats at an altitudinal range of $600-700 \mathrm{~m}$; they are widely distributed throughout the peninsula.

In communities of $P$. pumila-Ledum palustre-Sphagnum girgensohnii type $\left(16^{\text {th }}\right.$ cluster), predominance of Sphagnum girgensohnii in the bottom layer is conspicuous, and among the dwarf-shrubs, Ledum palustre has the highest abundance (Appendix 1 ). In addition to the title species, several other species in communities of this type also appear to be significant indicators: Sphagnum fuscum, S. capillifolium, Oxycoccus microcarpus, etc. (Appendix 2). These communities are common in nutrient-poor moist habitats, usually on Histosols, but sometimes they develop on steep slopes where the subsoil flow takes place. In the northern districts of the peninsula, Sphagnum-rich communities are found on the Cryosols, but in the eastern and central parts of Kamchatka, they also appear on Histosols around the mires.

For communities of $P$. pumila-Vaccinium uliginosum-Pleurozium schreberi type (17 $7^{\text {th }}$ cluster), a very high cover of Pleurozium schreberi in the moss layer is outstanding. Scarse Vaccinium uliginosum, V. vitis idaea, Ledum palustre and Empetrum nigrum grow in the field layer. The communities are related to mesic and mesotrophic habitats at a low-altitude range of 200-300 m; they are frequent in eastern, southern and central Kamchatka.

(vi) Group of lichen-rich communities: In these communities, fruticose lichens, such as Cladonia arbuscula, C. rangiferina, Cetraria islandica, Flavocetraria nivalis, Thamnolia vermicularis and some others have a high cover. This group was presented only by the P. pumila-Ledum palustre-Cladonia spp. type (18 ${ }^{\text {th }}$ cluster). Among these communities, $P$. pumila layer has a cover of less than $50 \%$ and a height of no more than $1 \mathrm{~m}$. Dwarf-shrubs (Ledum palustre and Vaccinium uliginosum) and some species of lichens (Cladonia arbuscula, C. rangiferina, Cetraria islandica, Flavocetraria nivalis, and Thamno- 
lia vermicularis) are constant and abundant. The communities are situated in the poorest and driest habitats at the upper limit of the subalpine zone on Leptosols of steep stony slopes and plateaus; they are widely distributed in all mountain ridges of the central, southern and eastern Kamchatka.

Although the species composition of several community types seems to be quite similar, the respective communities differ physiognomically well due to the proportions of species abundance. Certain differences can also be observed between the habitats' mean or median characteristics of community types (Table 3). For example, Rhododendron-rich communities (types 5 and 6) are often situated at comparatively high altitudes (800-900 m a.s.1.), whereas communities of $P$. pumila-Calamagrostis langsdorffii-Rubus chamaemorus type (12) and P. pumila-Chamaepericlymenum suecicum-Equisetum sylvatica type (13) are usually found in lower habitats. At the same time, the fern-rich and Calamagrostis-dominated communities were developed in the most nutritious-rich habitats.

Through cross-tabulation (Table 4), we can obtain a firmer idea about the frequency of different communities on the slopes of various exposition. Thus, communities of $P$. pumila pure type are usually situated on plains or slopes of southern exposition and almost lacking on the east-exposed slopes; shrub-rich communities are favoured on plains, more modestly occurring on the north and south slopes and less on the east and west slopes; herb-grass-rich stands prefer plains and western slopes, whereas moss-rich and lichen-rich communities are mainly formed on north-facing slopes.

Table 4. Exposition of habitats of different type communities. Type group notations as in Figure 3.

\begin{tabular}{|c|c|c|c|c|c|c|c|c|c|c|c|}
\hline \multirow{2}{*}{$\begin{array}{l}\text { Community } \\
\text { type }\end{array}$} & \multirow{2}{*}{$\begin{array}{l}\text { Type } \\
\text { group }\end{array}$} & \multicolumn{8}{|c|}{ Exposition } & \multirow[t]{2}{*}{ Plain } & \multirow[t]{2}{*}{ Total } \\
\hline & & $\mathrm{N}$ & NW & W & SW & $S$ & SE & $E$ & $\mathrm{NE}$ & & \\
\hline 1 & P. pumila & 2 & 3 & 4 & 8 & 3 & 2 & & 1 & 21 & 44 \\
\hline 2 & Shrub & & 2 & 1 & & 3 & 1 & 1 & 1 & 6 & 15 \\
\hline 3 & Shrub & & & 5 & & & & 3 & 2 & 15 & 25 \\
\hline 4 & Shrub & 1 & & 4 & 2 & 1 & & 2 & 2 & 5 & 17 \\
\hline 5 & Shrub & & & 1 & 1 & & 1 & 1 & 1 & 2 & 7 \\
\hline 6 & Shrub & 2 & & & & & 1 & 1 & & 4 & 8 \\
\hline 7 & DwShrub & & & 5 & 2 & & 1 & 3 & 1 & 9 & 21 \\
\hline 8 & DwShrub & 2 & 1 & 2 & & 1 & 1 & 1 & 1 & 6 & 15 \\
\hline 9 & DwShrub & 2 & & & 1 & 3 & & 1 & & 8 & 15 \\
\hline 10 & DwShrub & 1 & 4 & 5 & 4 & 1 & 1 & 3 & 3 & 9 & 31 \\
\hline 11 & HGrass & & & 7 & & 1 & & 3 & 1 & 2 & 14 \\
\hline 12 & HGrass & 1 & 3 & & 1 & 1 & & & 1 & 5 & 12 \\
\hline 13 & HGrass & 1 & & & & & & 2 & 1 & 1 & 5 \\
\hline 14 & Moss & 4 & 2 & 1 & & 1 & & 1 & 3 & 1 & 13 \\
\hline 15 & Moss & 1 & & 1 & 1 & 1 & & & 1 & 9 & 14 \\
\hline 16 & Moss & 4 & & 1 & & 1 & & & 1 & 1 & 8 \\
\hline 17 & Moss & 1 & 2 & 2 & 2 & & 1 & 1 & & 1 & 10 \\
\hline 18 & Lichen & 4 & 1 & & & & & & 2 & 1 & 8 \\
\hline Total & & 26 & 18 & 39 & 22 & 17 & 9 & 23 & 22 & 106 & 282 \\
\hline
\end{tabular}




\section{Discussion}

By virtue of a very long south-north reach, mountainous topography, volcanic activities and marine impact, several gradients of habitat conditions accruing from these phenomena are distinctly expressed on the Kamchatka Peninsula. Due to the extremely wide ecological tolerance, $P$. pumila stands are found here in a very large scope of habitats, thus distinguishing a substantial variation of their communities. According to Khomentovsky (1995), the main environmental factors that determine the diversity of P. pumila stands on the Kamchatka Peninsula are habitat moisture, soil fertility and light conditions. Our results confirm at least a significant impact of the first two factors; the lightness of the habitat was not directly measured in the current study, but only as a potential insolation in terms of habitat exposition. Based on these assessments, lightness/insolation has no considerable effect on species richness or the cover of vegetation layers.

In Japan (Okitsu \& Ito, 1984, 1989; Okitsu, 1998; Kolbek et al., 2003) and in the mountains of Sikhote-Alin (Grishin et al., 1996), P. pumila stands form a distinct vegetation belt (zone) above the forest limit. The same has been observed on the altitudinal distribution of the Pinus mugo communitites in Europe (Ellenberg, 1996; Šibik et al., 2010). On the Island of Hokkaido, P. pumila often occupies the deforested areas in the boreal subalpine zone that is generally intrazonal, and the altitudinal ranges of P. pumila belt vary from 200 to $500 \mathrm{~m}$, being independent at the top of the mountains (Okitsu \& Ito, 1989). Locally, they replace the Betula ermanii forests at the altitudinal forest limit and can reach the altitude of up to $1850 \mathrm{~m}$ (Okitsu, 2003); at the sites, $P$. pumila is also an undergrowth element of Larix gmelinii (= L. cajanderi) forests (Okitsu \& Ito, 1989; Okitsu, 1998).

In Hokkaido, the development of $P$. pumila thickets is associated with peculiar environmentally restricted regions where the thermal regime potentially permits the forest growth, but due to strong winds, heavy snowfall in winter and exposure of a rocky substrate, the forest development is hindered (Okitsu, 2002, 2003). For this reason, in the Taihetsu mountain range in central Hokkaido, P. pumila occurs mainly on gentle slopes in sheltered depressions on mountain tops and on deep leeward slopes that descend from the edge of a plateau; its height and cover declines with increasing wind exposure and reduced snow depth (Okitsu \& Ito, 1984, Okitsu 2002). The thermal conditions in the growing season of the P. pumila zone in Hokkaido do not coincide with any specific value of the warmth index (Okitsu \& Ito, 1984, 1989). Okitsu (1984) observed that the altitudinal difference between the ridge top and the forest limit tends to be wider on the northand west-facing slopes, which are windward sides to the prevailing winds in winter, and narrower in south- and east-facing leeward slopes.

On Mt. Vysokaya, the Central Sikhote-Alin, Grishin et al. (1996) pointed out that P. pumila forms a narrow but clear strip that is about a few tens of meters wide. The structure of these communities varies greatly depending upon the position on the slope and the shape of the terrain. There, the heterogeneity of dwarf pine communities is mainly determinated by the habitat's moisture, insolation and distribution of snow cover. The authors also emphasized on the importance of fires, which have had a strong impact on the structure of subalpine vegetation for a long time. The same can be observed in large areas in regions of active volcanism in Central, Eastern and Southern Kamchatka (Neshatayeva, 2011).

On the Kamchatka Peninsula, the altitude of the subalpine zone occupied by $P$. pumila stands is altered by variation in different regions of the peninsula. In some areas, mainly in southern Kamchatka, the $P$. pumila belt has developed almost from sea level, whereas on Sredinnyi mountain range, Malkinskiy range, on the water- 
shed between Yurtovaya river and Ozernaya Kamchatka river, it ascends to the altitude range of 1100-1200 m. In eastern Kamchatka (in the Kronotsky Nature Reserve), communities of Pineta pumilae hylocomiosa and P.p. herbosa occurring on steep smooth rocks, predominate in the altitude range of 700-900 m, but sometimes occur up to $1000-1100$ m a.s.l.. On the Kronotsky Peninsula extending far into the ocean, $P$. pumila belt including communities of P. p. fruticulosa and P. p. lichenosa is located much lower, at an altitudinal range of 150-300 m, locally reaching $400 \mathrm{~m}$ a.s.l.. On the eastern macroslope of the Sredinnyi mountain range (in the vicinity of Esso village), P. pumila belt has developed again at an altitudinal range of $700-900 \mathrm{~m}$, but on the eastern slopes of the Klyuchevskaya group of volcanos, it is found in the limits of 900-1200 m.

Unlike Japan, where $P$. pumila stands grow only in the subalpine belt/zone (Suzuki, 1964; Kobayashi, 1971; Okitsu, 2003), on the Kamchatka Peninsula, due to the considerably wide scope of environmental conditions, the habitat gradients for P. pumila are much longer; on Kamchat$\mathrm{ka}$, these communities occur attitudinally from sea level to high mountains and geographically from the southern extremity of the peninsula to the Kamchatka Isthmus and the Koryak Upland. Thus, herein, $P$. pumila also grows in climatic conditions corresponding to the northern-boreal and subarctic zones lacking in Japan. While in the southern and northern parts of the peninsula only two vegetation belts (subalpine and mountain tundra) are represented, in the Central Valley four vegetation belts can be clearly distinguished: dominated by coniferous forests (mountain-taiga), $B$. ermanii forests, $P$. pumila stands and mountain-tundra (Neshatayeva, 2009, 2011). Therefore, the typological diversity of $P$. pumila stands on the Kamchatka Peninsula is remarkably higher than in Japan or in the continental regions of Eastern Siberia and the Russian Far East. As community site types are changing along the nutrition and moisture gradients, $P$. pumila stands vary from xeric lichen-dominated communities to wet Sphagnum-rich stands, and from nutrient-poor dwarf-shrub and lichen-rich communities to meso-eutrophic herb and fern-rich communities. The latter already represent a syntaxonomical continuum towards Alnus fruticosa var. kamtshatica communities.

According to the results of multiple regression analysis carried out in the present study, the cover of P. pumila is not significantly dependent on altitude. Still, a certain negative trend is observable - together with the cover, its height decreases and more light reaches the lower layers of vegetation. This will promote a higher diversity of dwarf-shrub, herb, and especially lichen species. It should be noted that, in some places on Kamchatka, a similar relation can also be followed between the cover of P. pumila and the lower layers at almost on the same altitudinal level. Consequently, the cover of $P$. pumila creates an amazingly expressed gradient for the lower layers: if its projective cover exceeds $90 \%$, the vegetation of the lower layers may be totally lacking; although the P. pumila stand is sparse (cover less than 50\%), the lichens, mosses and dwarf-shrub species that tolerate/prefer more light will considerably increase their species richness. Moreover, in addition to P. pumila, the shrub layer has a negative effect to the underlaying dwarfshrubs and lichens cover, while the herb layer adversely affects the development of the moss layer. In the Taihetsu mountains, Okitsu (2002) observed that in areas of a shallow snow cover P. pumila increases the accumulation of snow around the shrubs and thus encourages the spread of the stand.

In conformity with the altitudinal gradient, the change in the species composition of the communities is clearly expressed. At high altitudes, P. pumila occurs on steep slopes of ridges and/or in places too rocky for Alnus fruticosa var. kamtschatica thickets. 
At higher altitudes, dwarf-shrubs, such as Vaccinium vitis-idaea, $V$. uliginosum, Empetrum nigrum, Ledum decumbens and several fruticose lichens (Cladonia arbuscula, C. rangiferina, C. stellaris, Cetraria islandica, Flavocetraria nivalis, and Thamnolia vermicularis) are dominating. In lower altitudinal level, the cover of the herb layer is higher and mesic boreal herb-rich assemblages of species, such as Maianthemum dilatatum, Trientalis europaea, Linnaea borealis, Lycopodium annotinum, and Oxalis acetosella, are typical. On the sea shore level along the eastern coast of Kamchatka, small patches of $P$. pumila are also found in the Betula ermanii forests. Among these patches, the forest species (Maianthemum dilatatum, Gymnocarpium dryopteris, Trientalis europaea, Solidago spiraeifolia, Chamerion angustifolium and some others) occasionally occur, especially in less dense thickets of dwarf-pine where light can reach the field and bottom layers. Similarly, in the $P$. pumila patches occurring among the Alnus fruticosa thickets, some herbs and ferns belonging to the undergrowth of the dwarf-alder communities can be found: Cirsium kamtschaticum, Veratrum oxysepalum, Cacalia kamtschatica, Dryopteris expansa, Athyrium filix-femina, Phegopteris connectilis, etc.

Attempting to extrapolate the dependence of the distribution of $P$. pumila communities on altitude, it can be said that:

(i) At lower altitudes (150-400 m) generally, the herb-grass-rich communities dominated in the field layer by Calamagrostis purpurea ssp. Langsdorffii, Lerchenfeldia flexuosa, Maianthemum dilatatum, Trientalis europaea, Lycopodium annotinum, etc. have developed;

(ii) At medium altitudes (450-600 m), shrub-rich communities dominated by Spiraea beauverdiana and/or Sorbus sambucifolia are typical;

(iii) To some extent higher (600-700 m), moss-rich communities with the abundant cover of Pleurozium schreberi, Polytrichum commune, Dicranum scoparium are widely distributed; (iv) At an altitude from 750 to $1000 \mathrm{~m}$, the psychrophilic communities with Rhododendron aureum appear;

(v) The uppermost position at an altitude from 700 to $1100 \mathrm{~m}$ is usually occupied by the dwarf-shrub-rich and/or lichen-rich $P$. pumila stands.

The fertility level of habitats has a significantly positive impact in the first place on the abundance of herb layer species, to a lesser extent on the cover of the shrub layer; at the same time, the growth of dwarfshubs and lichens is inhibited in relatively rich habitats well supplied with nutrients. In relation to the fertility gradient, the vertical structure of the communities is also changing explicitly: in lichen and/or moss-rich communities, only two layers are present; in habitats where the fertility level is higher, more complicated herb and shrub-rich communities with three layers develop.

On Mt. Ebeko, Paramushir Island, Okitsu et al. (2001) recorded a reduction in the total number of species from 50 at lower altitudes to 20 in communities at higher elevations. According to their explanation, many sporadic species grow at lower altitudes and non-volcanic mountains with a frequency below $10 \%$, while at higher altitudes almost all recorded species were common ones. The decreasing number of species towards a higher altitude may be partly related to the effect of repeated volcanism, wherein the plant communities remain, hence at an earlier stage of succession. Another issue associated with the effect of volcanic activity on plant communities is an admixture of species from different habitats, for the reason that repeated volcanism effectively aborts any development of habitat segregation, whereas at lower altitudes, many species only occur there. The insufficient time for maturation of plant communities under the impact of volcanoes causes some species to occur only sporadically without a clear altitudinal tendency. In a recent study, we did not analyse changes in the number of species of 
P. pumila stands along the altitudinal gradient of individual mountains; therefore, the statements above were not verified. Based on the average number of species in the communities, it can be said that some types of herb-grass-rich and shrub-rich communities, but generally species-poor communities are found from the lowest to medium altitudes, while communities having the highest average number of species (some types of dwarf-shrub-rich and moss-rich communities) occur at medium altitudes. Here, it must also be noted that, whilst instead of lichen-rich communities, the highest average location on Kamchatka have the communities of P. pumila-Rhododendron aureum-Dicranum scoparium type and P. pumila-Vaccinium uliginosum-Ceratodon purpureus type, the linear consecution of altitudinal belts of vegetation is often disturbed by several local factors, mainly by volcanic activities.

The thickness of the snow cover and exposition has only a modest effect on the vegetation of $P$. pumila stands on Kamchat$\mathrm{ka}$. Due to the impact of the cold-water seas (Sea of Okhotsk, Bering Sea and the northern part of the Pacific Ocean) that surround the pensinsula, the climate is humid and rather cold, and the thickness of the snow cover is usually more than $1 \mathrm{~m}$ everywhere. In the eastern coastal regions, the average snow thickness is even more than $2.5 \mathrm{~m}$ (Kondratyuk, 1974). Regarding the exposition, it seemed in our study that on the slopes that had exposition towards the northern rumbs, only the cover of the moss layer was significantly promoted; whereas for the cover of dwarf-shrubs and herbs, the exposition was included in the regression models, but as a non-significant factor.

The most widely distributed $P$. pumila communities were dominated by dwarfshrubs and mosses in the lower layers, and occupied the middle part of the moisture and fertility gradients of the habitats (Neshatayeva, 2011), which were also confirmed by the ordination analysis results in the present paper. Generalizing the facts about habitat conditions, which are related to those geographical distributions and of P. pumila stands on Kamchatka, we can conclude that:

(i) In eastern Kamcahtka, the P. pumila stands form a major vegetation type at an altitudinal range of $700-900 \mathrm{~m}$, and its communities occupy ledges and gentle slopes of volcanic upland, in which they can locally spread to $1000-1100 \mathrm{~m}$, growing there on volcanic plateaus ( $P$. pumila communities with dwarf-shrubs and lichens). On the Kronotsky Pensinsula, the vegetation belts are situated at a lower position due to the oceanic climate and permafrost, and the P. pumila stands start there from the coast up to $400-450 \mathrm{~m}$ upwards, being more pronounced at an altitudinal range of $150-300 \mathrm{~m}$. A similar inversion is characteristic to the flat depressions between the mountain ranges and the river valleys, where the cold air masses that descend from the mountains are standstill. There, the $P$. pumila stands are intermixed with the thickets of Alnus fruticosa covering the deeper slopes. Around the Kronotsky Lake, P. pumila stands occur at an altitudinal range of $900 \mathrm{~m}$ and higher, being replaced by tundra communities.

(ii) Alnus fruticosa thickets dominate on the southeastern coast of the Kamchatka Peninsula, and P. pumila communities are represented within them as comparatively small patches located on drier and nutrient-poor slopes of the northern and western exposition. In the southern part of the Central Valley, the P. pumila stands (with Rhododendron aureum, dwarf-shrubs and/ or lichens) are typical at an altitudinal range of 900-1200 m. On the eastern slope of the Sredinnyi Mt. Range, in the vicinity of Esso village, at an altitudinal range of 700-900 m, almost all the community type groups of $P$. pumila appear. On the western slopes of the volcanic plateau of the Kluchevskaya group of volcanoes, the $P$. pumila belt is situated at an altitudinal range of $850-1200 \mathrm{~m}$. There the stands in 
vast areas are damaged by contemporary volcano eruptions.

(iii) On the western coast of the peninsula, the P. pumila stands cover relatively small areas, usually on slopes, hillocks and periphery of mire (paludified) habitats.

(iv) In southern Kamchatka, the communities of $P$. pumila can be found on the western (Sea of Okhotsk) coast; on the southeastern (Pacific) coast, they occur relatively seldom, only on the rocky capes; however, in the Southern Kamchatka Nature Reserve, a large variety of them grow on the slopes of the volcanic plateaus.

(v) On Karaginsky Island, P. pumila stands cover about $35 \%$ of the territory, occupying mainly the mountain slopes, but also the Bering Sea coast. The stands cover the watershed areas and terraces with relic peat deposits up to an altitudinal range of 500-600 m. Here, pure stands of P. pumila and/or those with Spiraea beauverdiana or Sorbus sambucifolia are common.

The first brief floristical overview of P. pumila stands on Kamchatka Peninsula was published by Komarov $(1912,1927)$ and the first typological characterization of its communities in southern Kamchatka was published by Hultén (1927), who described three community types (associations): (i) Spiraea-moss-rich, (ii) SpiraeaSphagnum-rich and, (iii) Rhododendronmoss-rich. Based on studies in Central Kamchatka, Lipshits \& Liverovskii (1937) supplemented this list ten years later with tree associations: Pinetum pumilae purum, P. pumilae spiraeosum and P. pumilae rhododendrosum. Later, numerous scientists described some other associations of the $P$. pumila stands in the Russian Far East and north-eastern Siberia, but these classifications were based on various methodological approaches and were therefore often poorly comparable.

The first classification of P. pumila stands for northern Japan (Hokkaido Island) was elaborated by Tatewaki (1963). Based on dominant species of different layers, he distinguished between six associations: 1)
P. pumila-Rhododendron aureum-Empetrum nigrum var. japonicum; 2) P. pumila-Arctous alpina var. japonica-Vaccinium uliginosum; 3) P. pumila-Ledum palustre; 4) P. pumilaSorbus matsumurana; 5) P. pumila-Sasa kurilensis; 6) P. pumila without lower layers. Suzuki (1964) and Suzuki \& Umezu (1965), following the principles of the Braun-Blanquet classification approach, estimated in Central Japan (Honshu mountains) only one association: Vaccinio-Pinetum pumilae, alliance Vaccinio-Pinion pumilae (Suzuki, 1964).

Kobayashi (1967), using the same methodological approach, studied the $P$. pumila communities on the Taisetsu and Hidaka Ranges (Hokkaido). He described three associations there: 1) Sorbeto-Pinetum pumilae, 2) Rubeto-Pinetum pumilae, and 3) Ledeto-Pinetum pumilae. The first of them is close to the association P. pumila-Sorbus matsumurana and the last one to the association P. pumila-Ledum palustre distinguished by Tatewaki (1963). Later, Kobayashi (1971) developed the classification of P. pumila communities for the whole of Japan. Within the alliance Vaccinio-Pinion pumilae Suzuki (1964) distinguished between and characterized four broad associations: 1) Ledo-Pinetum pumilae, 2) Cetrario-Pinetum pumilae, 3) Rhodoro-Pinetum pumilae, and 4) Rubo-Pinetum pumilae. These associations were further divided into 16 sub-associations.

In Hokkaido, Okitsu \& Ito (1984) distinguished between four types of dwarf-pine communities: 1) Empetrum-Rhododendron type, best represented on leeward slopes, which are somewhat protected from strong winds and where the cover of $P$. pumila is high, 2) lichen type, occurring in more severe habitats, 3) Empetrum-Loiseleuria procumbens-Diapensia lapponica type and, 4) Empetrum-Loiseleuria-Diapensia sparse type (differentiated by the open canopy of P. pumila). Communities of the last two types occupied more exposed positions, the latter being presented in the most extreme conditions. Types 1, 2 and 3 are anal- 
ogous to Kamchatka subalpine $P$. pumila schrubs (Pinetum pumilae rododendrosum, Pinetum pumilae lichenosum and Pinetum pumilae fruticulosum).

Neshatayeva (2011) published a detailed synopsis about $P$. pumila stands on the entire Kamchatka Peninsula. The empirical classification based on 379 relevés was elaborated using the dominant-determinant species and classification approach of the Russian geobotanical school (Neshatayeva, 2004). Based on soil moisture and fertility, nine habitat site types and 15 associations were established, along with four sub-associations and 32 variants.

When comparing these results with community types established on the basis of multivariate analysis in the present study, in most cases, we can find a fairly good correspondence between them, but not always:

(i) The first variant of P. pumila pure type ( $1^{\text {st }}$ cluster) corresponds to the association Pinetum pumilae oligoherbosum subass. typicum, and subass. oligofruticulosum.

(ii) The P. pumila-Spiraea beauverdianaCalamagrostis langsdorffii type ( $2^{\text {nd }}$ cluster $)$ corresponds to the association Pinetum pumilae spiraeosum beauverdianae.

(iii) The P. pumila-Sorbus sambucifoliaMaianthemum dilatatum type ( $3^{\text {rd }}$ cluster) corresponds to the association Pinetum pumilae sorbosum sambucifoliae.

(iv) The P. pumila-Sorbus sambucifoliaGymnocarpium dryopteris type ( $4^{\text {th }}$ cluster) corresponds to Pinetum pumilae sorbosum sambucifoliae var. hylocomiosum.

(v) The P. pumila-Rhododendron aureumPolytrichum commune type ( $5^{\text {th }}$ cluster) and

(vi) the P. pumila-Rhododendron aureumDicranum scoparium type (6 $6^{\text {th }}$ cluster) correspond to the association Pinetum pumilae rhododendrosum aurei.

(vii) The P. pumila-Vaccinium uliginosum-Ceratodon purpureus type ( $7^{\text {th }}$ cluster) corresponds to the association Pinetum pumilae hylocomioso-fruticulosum subass. typicum var. laricetosum.

(viii) The $P$. pumila-Vaccinium vi-
tis-idaea-Stereocaulon paschale type $\left(8^{\text {th }}\right.$ cluster) coincides best with the association Pinetum pumilae herboso-fruticulosum.

(ix) The P. pumila-Empetrum nigrumCladonia gracilis type ( $9^{\text {th }}$ cluster) corresponds to Pinetum pumilae hylocomioso-fruticulosum.

(x) The P. pumila-Ledum palustre-Sphagnum lenense type communities ( $10^{\text {th }}$ cluster) corresponds to the association Pinetum pumilae herboso-fruticulosum var. calamagrostidosum.

(xi) The P. pumila-Lerchenfeldia flexuosaChamerion angustifolium type (1 $11^{\text {th }}$ cluster) and

(xii) P. pumila-Calamagrostis langsdorffiiRubus chamaemorus type (12 ${ }^{\text {th }}$ cluster) correspond best to the association Pinetum pumilae calamagrostidosum var. lerchenfeldiosum and associations of the Pineta pumilae pteridosa group, i.e. the associations Pinetum pumilae phegopteridosum and Pinetum pumilae dryopteridosum.

(xiii) The P. pumila-Chamaepericlymenum suecicum-Equisetum sylvaticum type $\left(13^{\text {th }}\right.$ cluster) corresponds to the association Pinetum pumilae chamaemori-rubosum var. chamaepericlymenosum.

(xiv) The P. pumila-Dicranum spp.-Mnium thomsonii type ( $14^{\text {th }}$ cluster) corresponds to the association Pinetum pumilae hylocomiosum var. oligoherbosum.

(xv) The P. pumila-Dicranum spp.-Pol$y$ trichum commune type (15 ${ }^{\text {th }}$ cluster) corresponds to the association Pinetum pumilae hylocomiosum var. typicum.

(xvi) The P. pumila-Ledum palustreSphagnum girgensohni type ( $16^{\text {th }}$ cluster $)$ corresponds to the association Pinetum pumilae sphagnosum girgensohnii.

(xvii) The P. pumila-Vaccinium uliginosum-Pleurozium schreberi type (17 $17^{\text {th }}$ cluster) corresponds to the association Pinetum pumilae hylocomiosum var. oligofruticulosum.

(xviii) The P. pumila-Ledum palustreCladonia spp. type $\left(18^{\text {th }}\right.$ cluster $)$ corresponds to the association Pinetum pumilae cladinosum.

In the present study, we did not find 
a satisfactory correspondence for associations Pinetum pumilae nanoherbosum and Pinetum pumilae equsietosum sylvatici; through multivariate analysis, the communities of the former association are merged with the $11^{\text {th }}$ or $12^{\text {th }}$ cluster, and the communities of the latter association with the $13^{\text {th }}$ cluster.

The empirical classification focuses more on certain indicator species, which may lead to an overestimation of their importance and sometimes distinguishing subordinated units in order to emphasize some peculiarities or the individual features of communities (e.g. the height of $P$. pumila shrubs, the density of layers, the presence of some forest or tundra species, the altitudinal limits, etc.). The numerical classification is much more formal and rigorous; if there are no special procedures involved, the abundance of all species is objectively considered without subjectively aggravating any species. Moreover, the very rare communities, having a peculiar structure and subjectively awakening special interest, could be ignored by numerical classification as outliers or statistically unreliable objects due to infrequent occurences. Therefore, we cannot conclude here which of the compared classifications is better: it depends on which characteristics are considered more informative or correspond better with the aim of the classification.

Acknowledgements. This study was supported by the Russian Foundation for Basic Research (RFBR) grants 16-05-00736a, 19-05-00805a and by the European Regional Development Fund (Fibre Centre of Excellence). We are very grateful to Dr. V.V. Yakubov, Dr. I.V. Chernyadjeva and D.E. Himmelbrant for the determinaton of herbarium samples of vascular plants, mosses and lichens. We would like to express our gratitude to all participants of the Kamchatka expeditions for their kind assistance and help. We thank MSc. Kersti Unt for revising the English grammar used.

\section{References}

Braitseva, O.A., Melekestsev, I.V., Ponomareva, V.V., Sulerzhitsky, L.D., Pevzner, M.M. (Брайцева, О.А., Мелекесцев, И.В., Пономарева, В.В., Сулержицкий, Л.Д., Певзнер, М.M.) 1997. Geology and parameters of the largest explosive eruptions in Kamchatka for the last 10 thousand years. (Геология и параметры крупнейших эксплозивных извержений на Камчатке за последние 10 тыс. лет). - Russian science: to survive and recover. (Российская наука: выстоять и возродиться). Moscow, Nauka. 237-244. (In Russian).

Chertov, O.G. (Чертов, О.Г.) 1981. Ecology of Forest Lands: Soil and Ecological Study of Forest Sites. (Экология лесных земель: почвенно-экологическое исследование лесных местообитаний). Leningrad, Nauka. 192 pp. (In Russian).

Czernyadjeva, I.V. (Чернядьева, И.В.) 2012. Mosses of Kamchatka Peninsula. (Мхи полуострова Камчатка). St. Petersburg, Izdatel'stvo SPbGETU “LETI". 459 pp. (In Russian).

Dufrêne, M., Legendre, P. 1997. Species assemblages and indicator species: the need for a flexible asymmetrical approach. - Ecological Monographs, 67(3), 345-366. https://doi. org/10.2307/2963459.

Ellenberg, H. 1996. Vegetation of Central Europe together with Alps considering its ecology, dynamics and history. (Vegetation Mitteleuropas mit den Alpen: in ökologischer, dynamischer und historischer Sicht). Ulmer, Stuttgart. 1095 pp. (In German).

Grishin, S.Yu., Krestov, P., Okitsu, S. 1996. The subalpine vegetation of Mt. Vysokaya, central Sikhote-Alin. - Vegetatio, 127, 155-172.

Grushin, M.I. [Грушин, М.И.] 1961. Forest resources of Kamchatka. (Лесные ресурсы Камчатки). - Natural raw material resources of the Kamchatka region. (Сырьевые ресурсы Камчатской области). Moscow, Izdatel'stvo Akademii Nauk SSSR. 164-169. (In Russian).

Gusev, A.A., Ponomareva, V.V., Braitseva, O.A., Melekestsev, I.V., Sulerzhitsky, L.D. 2003. Great explosive eruptions on Kamchatka during the last 10,000 years: Self-similar irregularity of the output of volcanic products. - Journal of Geophysical Research, 108(B2), 2126. doi:10.1029/2001JB000312, 2003.

Hultén, E. 1927. Flora of Kamchatka and the Adjacent Islands. Kungl. Svenska Vetenskapsakademiens Handlingar. 3 Serien. Stockholm, Almqvist \& Wiksells. Bd. 5, 1, 1-346.

Hultén, E. 1968. Flora of Alaska and Neighboring Territories. Stanford, California, Stanford University Press. 1032 pp. 
Hultén, E. 1974. The plant cover of Southern Kamchatka. - Arkiv för Botanik utgivet av Kungl. Svenska Vetenskapsakademien. Andra Serien, 7, 181- 257.

Hultén, E., Fries, M. 1986. Atlas of North European Vascular Plants North of the Tropic of Cancer. Königstein, Koeltz Scientific Books. 996 pp.

Hundt, R. 1985. The application of area diagnose according to Meusel, Jäger and Weinert in the phytogeographical characterization of phytocoenoses. (Zur Nutzung der Arealdiagnosen nach Meusel, Jäger und Weinert zur pflanzengeographischen Charakterisierung von Phytozönosen). - Flora, 176(3-4), 325-340. https://doi.org/10.1016/ S0367-2530(17)30127-5. (In German with English summary).

Jongman, R.H.G., Ter Braak, C.J.F., Van Tongeren, O.F.R. 1995. Data Analysis in Community and Landscape Ecology. New York, Cambridge University Press. 299 pp. https:/ / doi.org/10.1017/CBO9780511525575.

Kabanov, N.E. (Кабанов, H.Е.) 1977. Conifer trees and shrubs of Far East. (Хвойные деревья и кустарники Дальнего Востока). Moscow, Nauka. 175 pp. (In Russian).

Kachinsky, N.A. (Качинский, H.А.) 1970. Physics of the soil. Part II. Water-physical properties and soil regimes. (Физика почвы. Часть 2. Водно-физические режимы и свойства почв). Moscow, Vysshaya shkola. 359 pp. (In Russian).

Kharkevich, S.S. (Харкевич, С.C.) 1984. Taxonomical composition and geographical distribution of vascular plants of Northern Koryakia (Kamchatka region). (Таксономический состав и географическое распространение сосудистых растений Северной Корякии (Камчатская область). Komarovskie chteniya, 31, 3-45. (In Russian).

Kharkevich, S.S. (Харкевич, C.C.) 1989. Plantae Vasculares Orientalis Extremi Sovietici. (Сосудистые растения Советского Дальнего Востока). Leningrad, Nauka. 4, 380 pp. (In Russian).

Khomentovsky, P.A. (Хоментовский, П.А.) 1995. Ecology of Siberian dwarf-pine (Pinus pumila (Pall.) Regel) in Kamchatka. (Экология кедрового стланика (Pinus pumila (Pall.) Regel) на Камчатке). Vladivostok, Dal'nauka. 226 pp. (In Russian).

Kobayashi, K. 1967. Phytosociological studies on Pinus pumila scrubs of the Daisetsu and the Hidaka ranges in Hokkaido, Japan. - Japanese Journal of Ecology, 17(5), 189-198. https:// doi.org/10.18960/seitai.17.5_189.

Kobayashi, K. 1971. Phytosociological studies on the scrub of dwarf pine (Pinus pumila) in Japan. - Journal of Science of the Hiroshima University, Series B, Div. 2 14, 1-52.
Kolbek, J., Valachovič, M., Ermakov, N., Neuhäuslová, Z. 2003. Comparison of forest syntaxa and types in Northeast Asia. Kolbek, J., Šrůtek, M., Box, E.O. (eds.). Forest Vegetation of Northeast Asia. Dordrecht, Springer, 28, 409-423.

Komarov, V.L. (Комаров, В. Л.) 1912. Travel across Kamchatka in 1908-1909. Kamchatka expedition of F.P. Ryabushinsky. Botanical Department. (Путешествие по Камчатке в 1908-1909 гг. Камчатская экспедиция Ф.П. Рябушинского. Ботанический отдел). St. Petersburg. 1, 456 pp. (In Russian).

Komarov, V.L. (Комаров, В.Л.) 1927. Flora of the Kamchatka Peninsula. (Флора полуострова Камчатки). Leningrad, Izdatel'stvo Akademii Nauk SSSR. 1, 339 pp. (In Russian).

Komarova, T.A. (Комарова, T.A.) 2004. Comparative estimation of environmental conditions on the basis of regime observations and ecological scales. (Сравнительная оценка условий среды на основе режимных наблюдений и экологических шкал). Komarovskie chteniya, 50, 28-59. (In Russian).

Kondratyuk, V.I. (Кондратюк, В.И.) 1974. The Climate of Kamchatka. (Климат Камчатки). Moscow, Gidrometeoizdat. 204 pp. (In Russian).

Konstantinova, N.A., Potemkin, A.D., Schljakov, R.N. 1992. Check-list of the Hepaticae and Anthocerotae of the former USSR. - Arctoa, 1(1), 87-127.

Krestov, P.V. 2003. Forest vegetation of easternmost Russia (Russian Far East). Kolbek, J., Šrůtek, M., Box, E.O. (eds.). Forest Vegetation of Northeast Asia. Dordrecht, Kluwer Academic Publishers, 28, 93-180. https: / / doi.org/10.1007/978-94-017-01433_5.

Lancaster, B.P. 1999. Defining and interpreting suppressor effects: Advantages and limitations. - Thompson, B. (ed.). Advances in Social Science Methodology. Bingley, UK, Emerald Group Publishing Limited, 5, 139-148.

Lipshits, S.Yu., Liverovskii, Yu.A. (Липшиц, С.Ю., Ливеровский, Ю.А.) 1937. Тhe soil and botanical studies and the problems of agriculture in the central part of the Kamchatka River valley. (Почвенно-ботанические исследования и проблема сельского хозяйства в центральной части долины реки Камчатки). - Proceedings of the Council for the study of productive forces, USSR Academy of Sciences. Ser. Kamchatka. Moscow, Leningrad, AN SSSR. 4, 220 pp. (In Russian).

Mazirov, M.A., Shein, E.V., Korchagin, A.A., Shushkevich, N.I., Dembovetskii, A.V. (Мазиров, М.А., Шеин, Е.В., Корчагин, А.А., Шушкевич, Н.И., Дембовецкий, А. В.) 2012. Field studies of soil properties: manual. (Полевые исследования свойств почв: учебное пособие). Vladimir, Izd-vo VIGU. 72 pp. (In Russian). 
McCune, B., Grace, J.B. 2002. Analysis of Ecological Communities. Gleneden Beach, Oregon, MjM Software Design. 300 pp.

McCune, B., Mefford, M.J. 2016. PC-ORD. Multivariate Analysis of Ecological Data. Version 7. Gleneden Beach, Oregon, MjM Software Design. 34 pp. [WWW document]. - URL https://static1.squarespace.com/ static/58f588c93e00be17785ced5d/t/5bc ccc404785d3d9aac3e266/1540148334020/ PBooklet7.pdf . [Accessed 8 July 2021].

Meusel, H., Jäger, E., Weinert, E. 1965. A Comparative Chorology of the Central European Flora. (Vergleichende Chorologie der Zentraleuropäischen Flora). Jena, Gustav Fischer Verlag. Bd. 1, 258 pp. (In German).

Mielke, P.W. Jr. 1984. Meteorological applications of permutation techniques based on distance functions. - Krishnaiah, P.R., Sen, P.K. (eds.). Handbook of Statistics. New York, Elsevier Science Publishers, 4, 813-830.

Neshatayeva, V.Yu. (Нешатаева, В.Ю.) 2004. Ecological-phytocoenological classification of the stone-birch forests in the Kamchatka Peninsula. (Эколого-фитоценотическая классификация сообществ каменноберезовых лесов полуострова Камчатка). - Vegetation of Russia, 6, 54-82. https://doi.org/10.31111/vegrus/2004.06.54. (In Russian with English summary).

Neshatayeva, V.Yu. (Нешатаева, В.Ю.) 2009. The vegetation of the Kamchatka Peninsula. (Растительность полуострова Камчатка). Moscow, Izdatel'stvo KMK. 537 pp. (In Russian).

Neshatayeva, V.Yu. (Нешатаева, B.Ю.) 2011. Siberian dwarf-pine (Pinus pumila (Pall.) Regel) communities in the Kamchatka Peninsula. (Сообщества кедрового стланика (Pinus pumila (Pall.) Regel) полуострова Камчатка). - Vegetation of Russia, 19, 71-100. (In Russian with English summary).

Okitsu, S. 1984. Control factors of the forest limit in Mt. Taisetsu, central Hokkaido, Japan. Japanese Journal of Ecology, 34, 439-444.

Okitsu, S. 1998. Distribution and growth of Pinus pumila Regel along the Larix gmelinii (Rupr.) Rupr. timberline ecotone of Mt. Dal'nyaya Ploskaya, Central Kamchatka. - Proceedings of the NIPR Symposium on Polar Biology, 11, 159-168.

Okitsu, S. 2002. Ecology of Boreal Vegetation of North-Eastern Eurasia. Tokyo, Kokon Shoin. 212 pp. (In Japanese with English summary).

Okitsu, S. 2003. Forest vegetation of Northern Japan and Southern Kurils. - Kolbek, J., Srůtek, M., Box, E.O. (eds.). Forest Vegetation of Northeast Asia. Dordrecht, Kluwer Academic Publishers, 28, 231-261. https:// doi.org/10.1007/978-94-017-0143-3_7.
Okitsu, S., Ito, K. 1984. Vegetation dynamics of the Siberian dwarf pine (Pinus pumila Regel) in the Taisetsu mountain range, Hokkaido, Japan. - Vegetatio, 58, 105-113. https://doi. org/10.1007/BF00044934.

Okitsu, S., Ito, K. 1989. Conditions for the development of the Pinus pumila zone of Hokkaido, northern Japan. - Vegetatio, 84, 127132. https:/ / doi.org/10.1007/BF00036513.

Okitsu, S., Minami, Y., Grishin, S.Yu. 2001. Ecological notes on the heath community on Mt. Ebeko, Paramushir Island, northern Kuriles. - Memoirs of National Institute of Polar Research, 54, 479-486.

Pielou, E.C. 1977. Mathematical Ecology. New York, John Wiley \& Sons. 385 pp.

Qian, H., Krestov, P., Fu, P.Y., Wang, Q.-L., Song, J.-S., Chourmouzis, Ch. 2003. Phytogeography of Northeast Asia. - Kolbek, J., Šrůtek, M., Box, E.O. (eds.). Forest Vegetation of Northeast Asia. Dordrecht, Kluwer Academic Publishers, 28, 51-91. https://doi.org/10.1007/978-94017-0143-3_4

Santesson, R., Moberg, R., Nordin, A, Tønsberg, T., Vitikainen, O. 2004. Lichen-Forming and Lichenicolous Fungi of Fennoscandia. Uppsala, Uppsala University, Museum of Evolution. 359 pp.

Sapozhnikov, A.P., Selivanova, G.A., Il'ina, T.M., Djukarev, V.N., Butovec, G.A., Gladkova, G.A., Gavrenkov, G.I., Zhilcov, A.S. 1993. Soil formation and the features of biological cycle of substances in the mountain forests of Southern Sikhote-Alin. (Почвообразование и особенности биологического круговорота веществ в горных лесах Южного СихотэАлиня). Khabarovsk, Dal'nauka. 267 pp. (In Russian).

Sokolov, I.A. (Соколов, И.А.) 1973. Volcanism and Pedogenesis (by example of Kamchatka). (Вулканизм и почвообразование (на примере Камчатки). Moscow, Nauka. 224 pp. (In Russian).

StatSoft. Inc. 2005. STATISTICA (data analysis software system), version 7.1. [WWW document]. - URL wWw.statsoft.com. [Accessed 8 May 2021].

Suzuki, T. 1964. A plant sociological review of alpine and subalpine vegetation of Inner Kurobe District, Japanese North Alps. (Pflanzensoziologische Übersicht auf alpinen und subalpinen Vegetation in inneren Kurobe Gebiet, Japanischen Nordalpen). Toyama, Nature of Japanese North Alps. Scientific Researches of the Toyama University, 219-254. (In German).

Suzuki, T., Umezu, Y. 1965. Dwarf pine shrubs and Alpine heaths inside Kurobe-Tateyama and Hakusan areas, Central Japan. - Japanese Journal of Ecology, 15(3), 113-124. https:// doi.org/10.18960/seitai.15.3_113. (In Japanese with German summary). 
Šibík, J., Šibíková, I., Kliment, J. 2010. The subalpine Pinus mugo-communities of the Carpathians with a European perspective. Phytocoenologia, 40(2-3), 155-188.

Tatewaki, M. 1963. The vegetation of the Daisetsu volcano group. - Ishikawa, T. (ed.). Scientific Researches of the Daisetsu volcano group. Tokyo, Reports of the Nature Conservation Society of Japan, 8, 25-59. (In Japanese with English summary).

Tikhomirov, В.А. (Тихомиров, Б.А.) 1949. Siberian dwarf-pine, its biology and usage. (Кедровый стланик, его биология и использование). Moskva, Izdatel'stvo MOIP. 106 pp. (In Russian).

Yakubov, V.V., Chernyagina, O.A. (Якубов, В.В., Чернягина, О.А.) 2004. Catalogue of the Flora of Kamchatka (vascular plants). (Каталог флоры Камчатки (сосудистые растения). Petropavlovsk-Kamchatsky, Kamchatpress. 165 pp. (In Russian).
Yasuda, M., Okitsu, S. 2012. Relationship between shoot elongation and tree-ring growth varies with the positional environment in Pinus pumila. - Journal of Horticultural Research, 66, 49-54.

Yurtsev, B.A. 1994. Floristic division of the Arctic. - Journal of Vegetation Science, 5(6), 765-776. https://doi.org/10.2307/3236191.

Zakharikhina, L.V., Litvinenko, Yu. S. (Захарихина, Л.В., Литвиненко, Ю.С.) 2011. Genetic and Geochemical Features of the Soils of Kamchatka. (Генетические и геохимические особенности почв Камчатки). Moscow, Nauka. 245 pp. (In Russian).

Received July 09, 2021, accepted August 31, 2021 


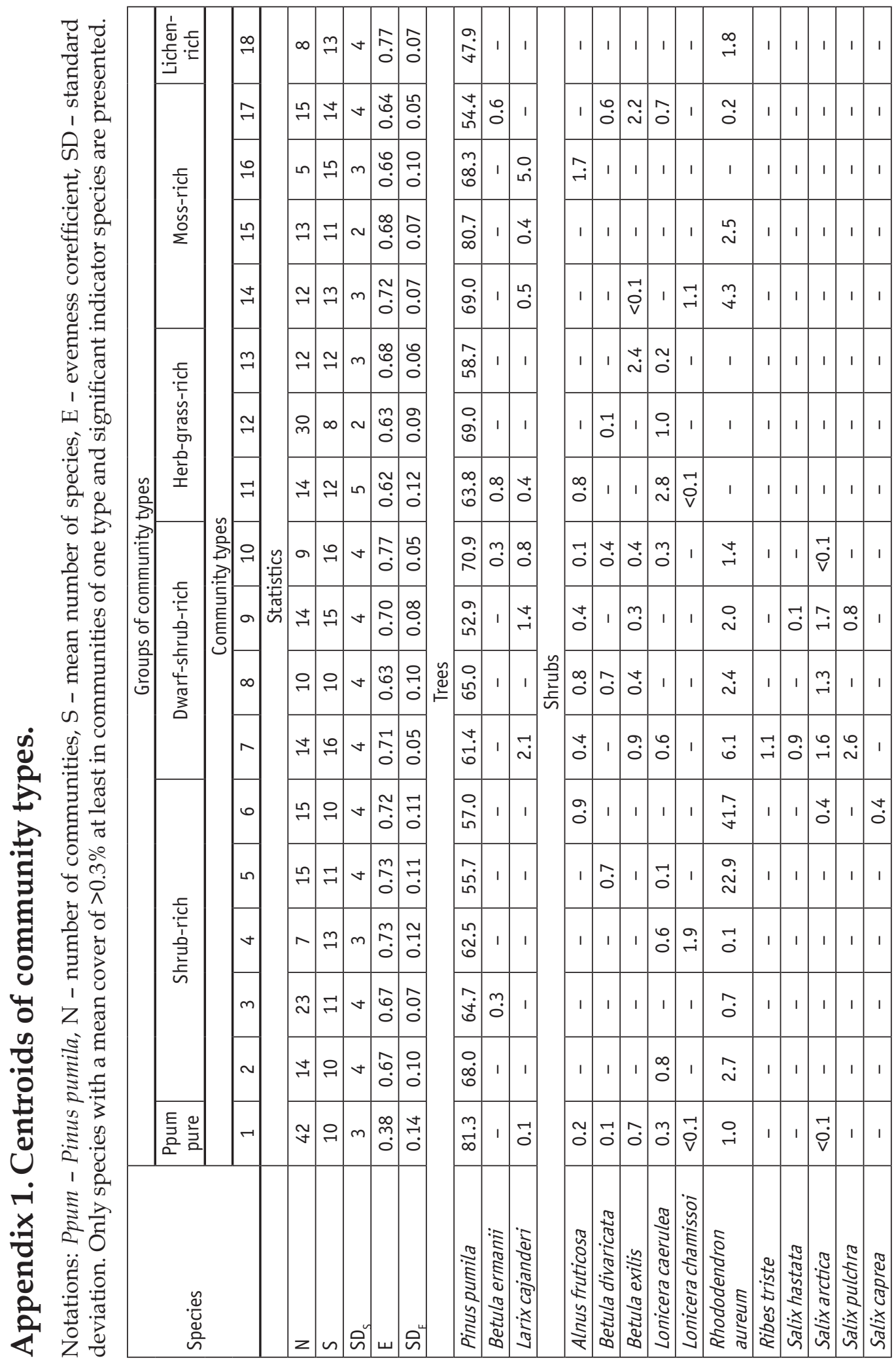




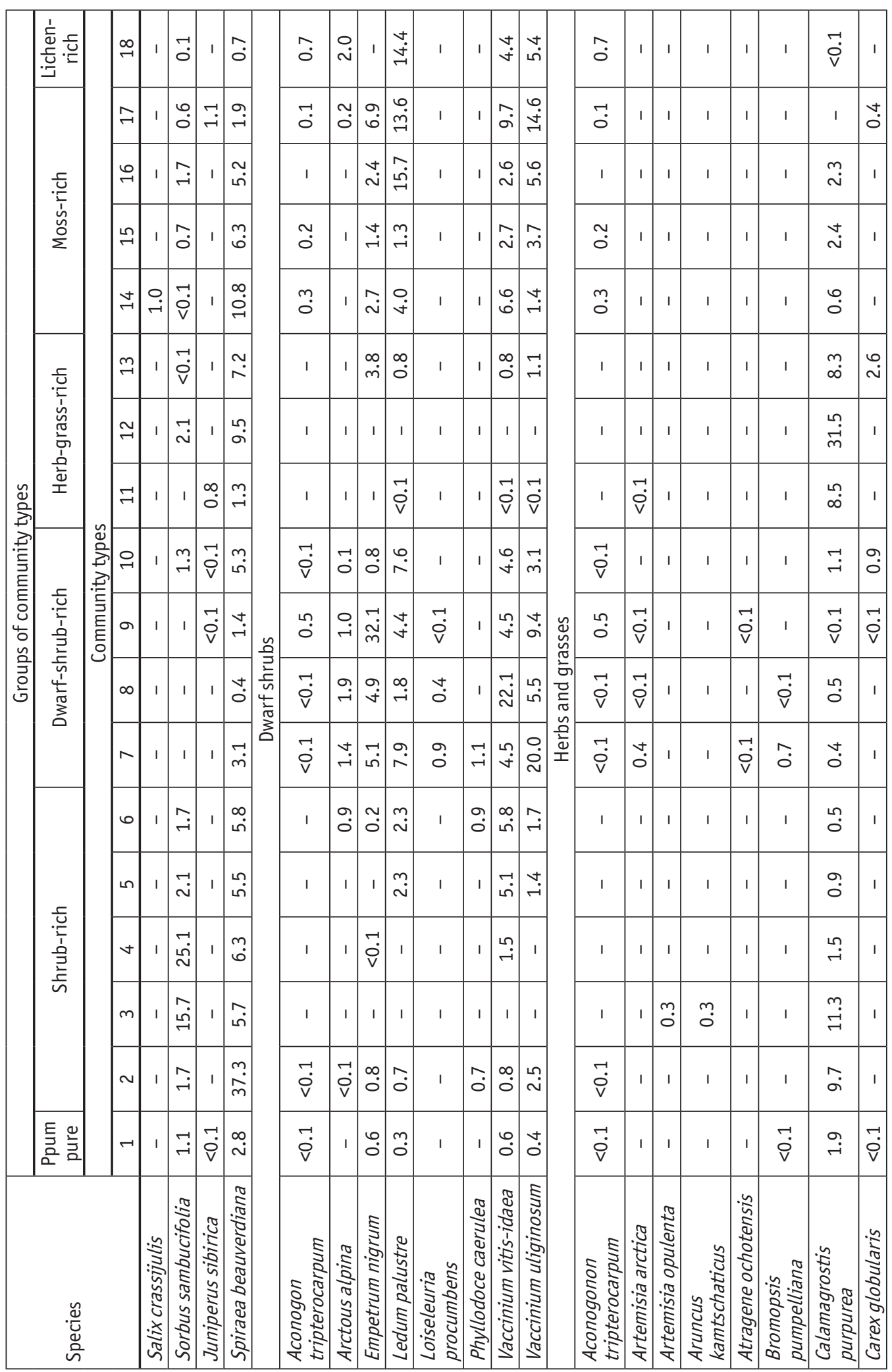




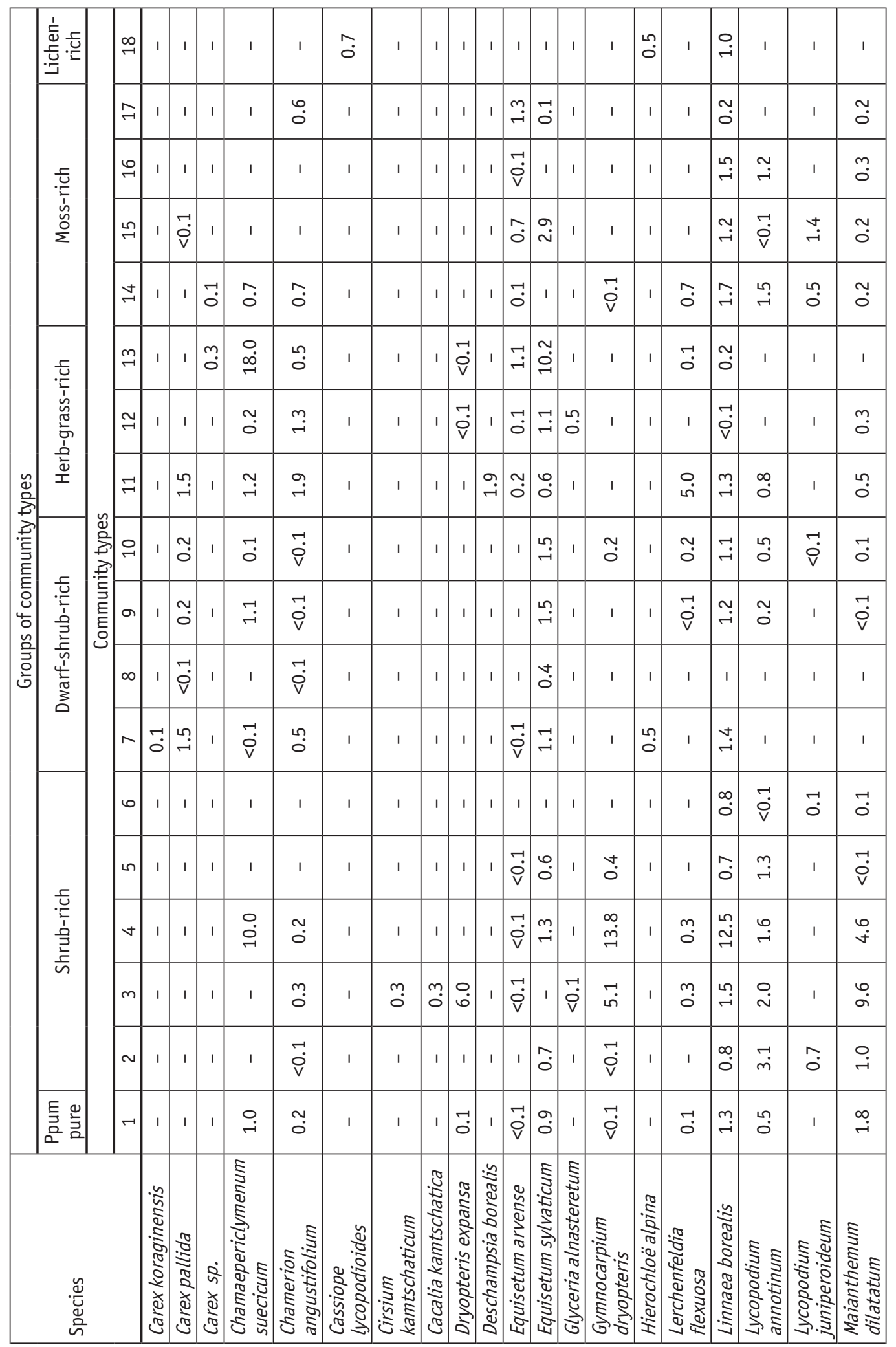




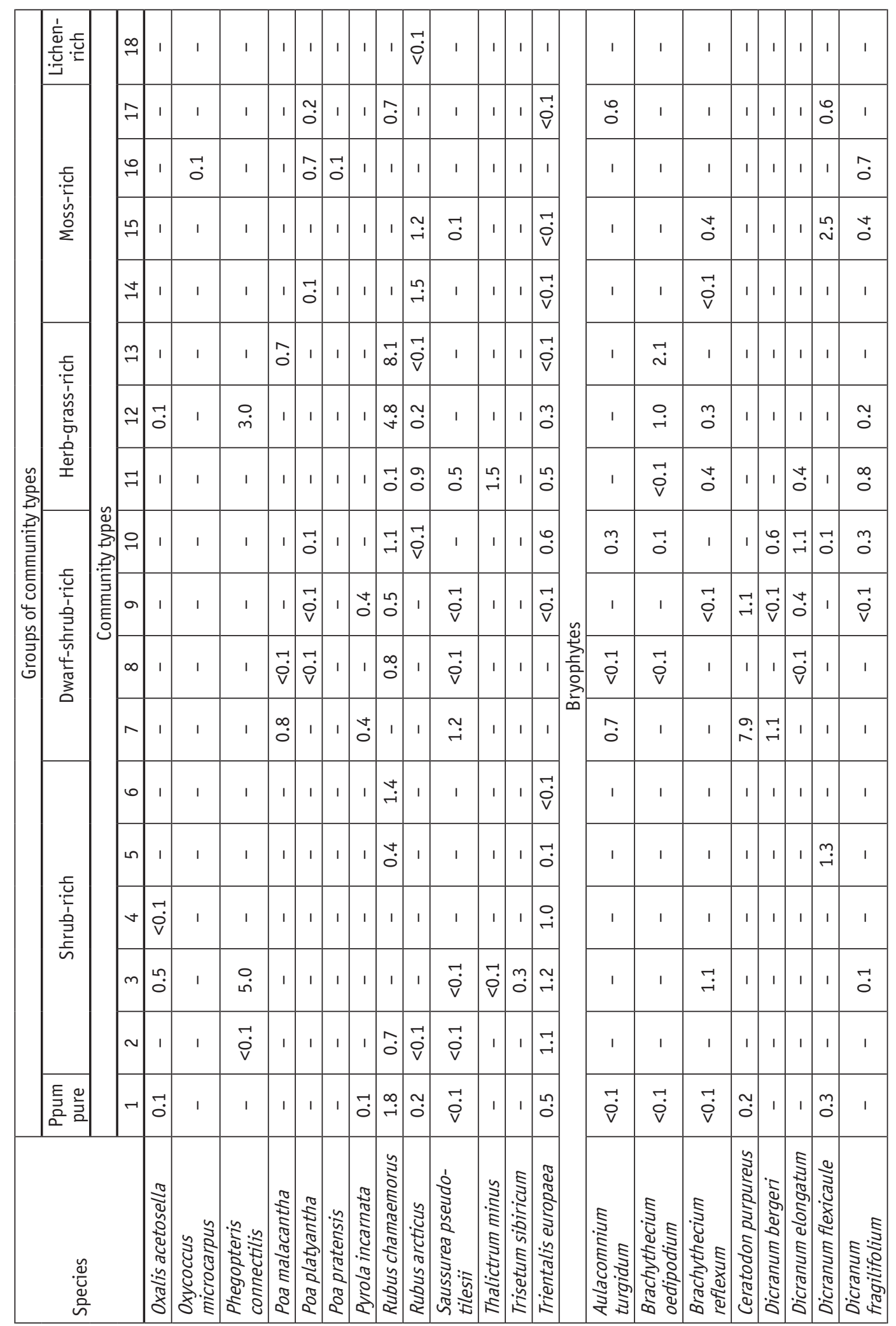




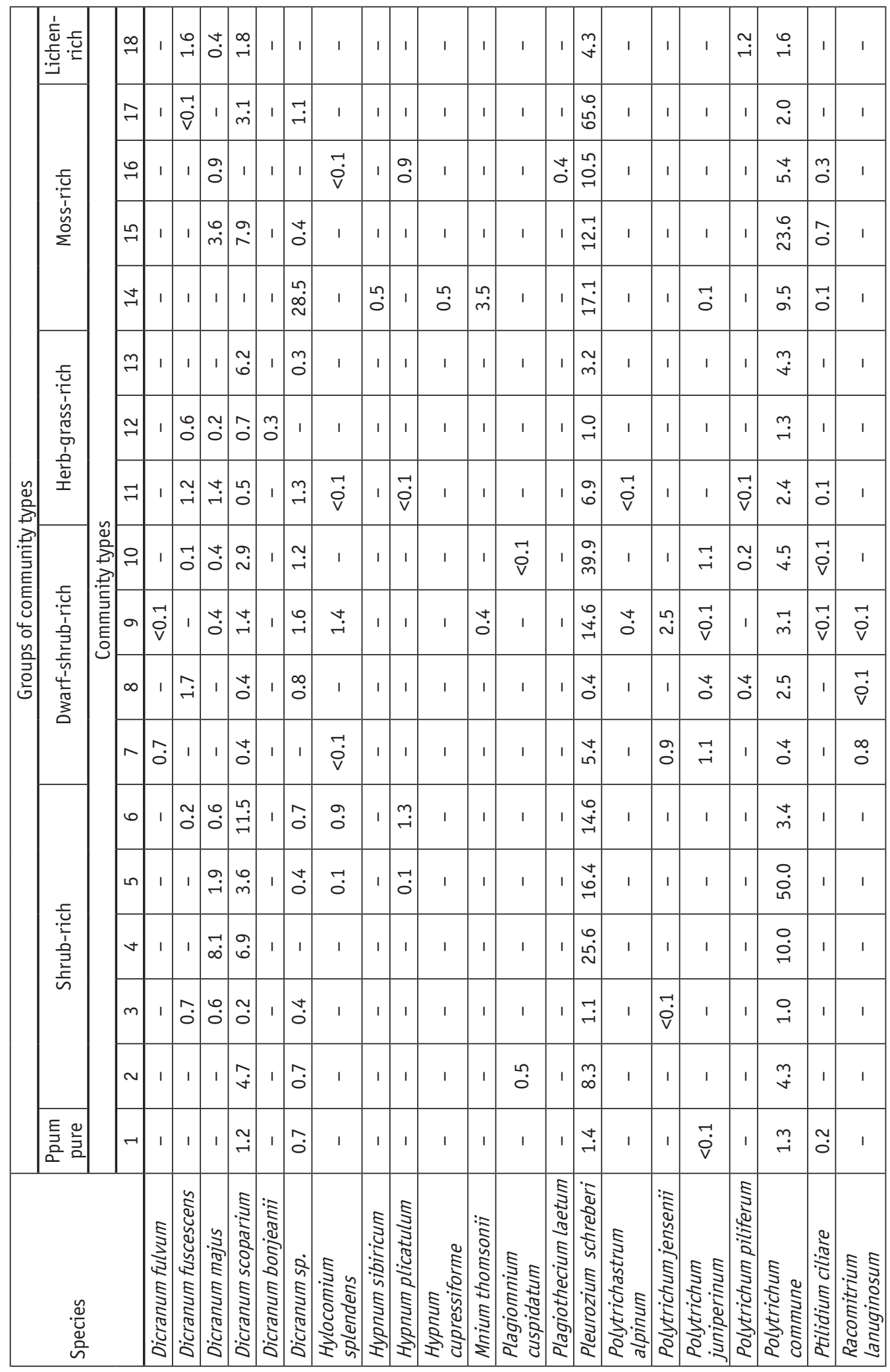




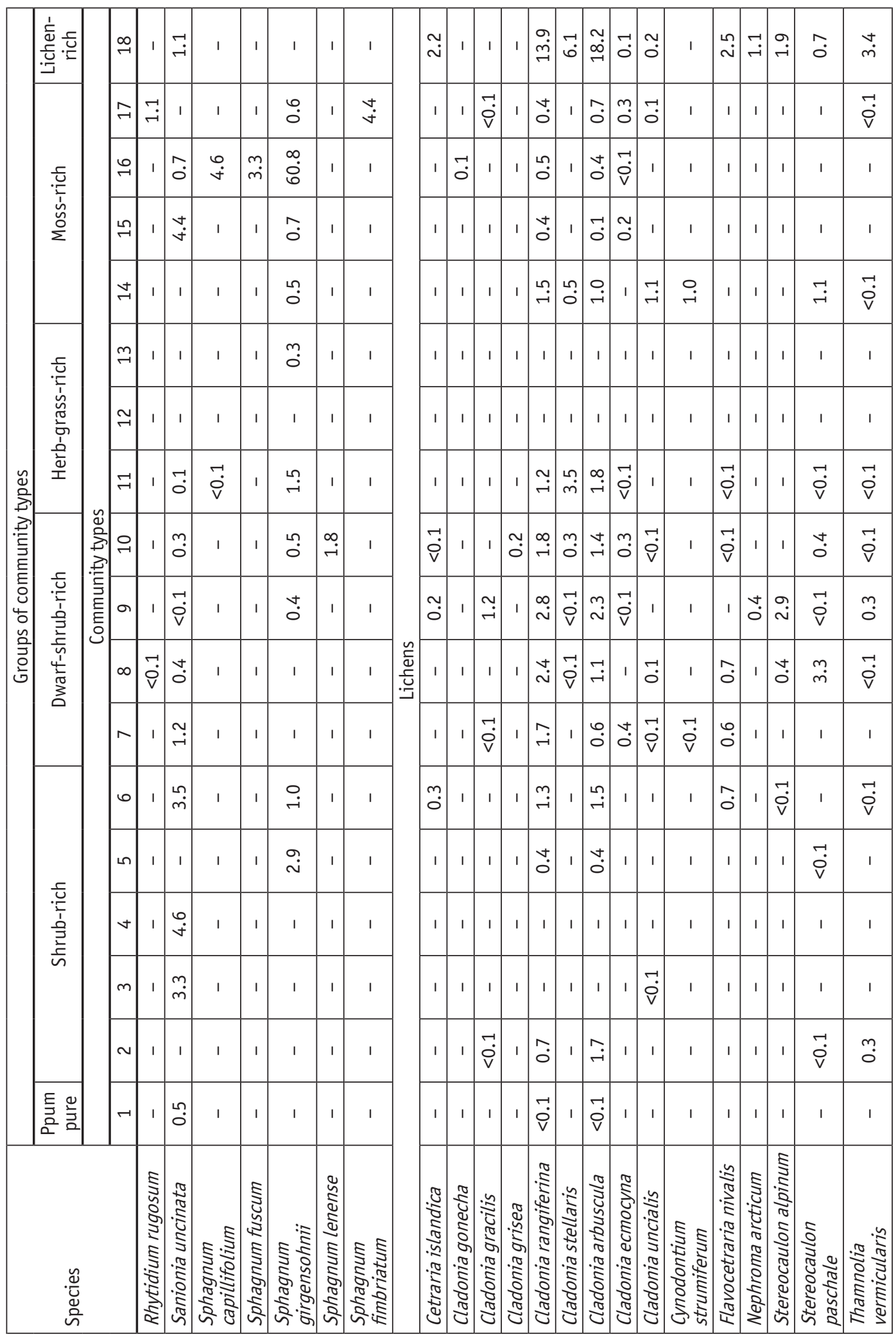




\begin{tabular}{|c|c|c|c|c|c|c|c|c|c|c|c|c|c|c|c|c|c|c|c|c|c|}
\hline$\stackrel{\infty}{\rightarrow}$ & $\checkmark$ & 0 & 0 & 0 & 0 & 0 & 0 & 0 & $r$ & 10 & 10 & $r$ & 0 & 0 & 0 & $\sim$ & $\neg$ & $r$ & In & 0 & \\
\hline 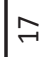 & |ما & $r$ & 0 & 0 & 0 & 0 & 10 & 0 & -1 & 0 & 0 & 0 & 0 & 0 & 0 & 0 & 0 & $\sim$ & 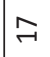 & 0 & \\
\hline 0 & 6 & $\checkmark$ & 0 & $c$ & 0 & $c$ & & 0 & $m$ & $r$ & 0 & $\checkmark$ & 0 & 10 & $\sim$ & $\neg$ & 0 & 0 & L & 0 & c \\
\hline$\stackrel{\stackrel{2}{\sim}}{\sim}$ & it & L & 0 & 0 & 0 & 0 & $\rightarrow$ & 0 & 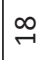 & 0 & 10 & $\sim$ & 0 & 0 & 우 웅 & $\stackrel{\rightrightarrows}{\digamma}$ & $\neg$ & $r$ & $\sim$ & 0 & \\
\hline$\stackrel{ \pm}{\sim}$ & 6 & $r$ & c & 0 & 0 & $c$ & 0 & 0 & 0 & 10 & 0 & $m$ & 0 & N & 0 & 0 & $\sim$ & 0 & $\neg$ & 0 & $c$ \\
\hline$\stackrel{m}{\rightarrow}$ & חص & 0 & c & 0 & 0 & 0 & 0 & 0 & $\sim$ & 0 & 0 & 0 & 0 & 0 & 0 & 0 & 0 & 0 & $r$ & 0 & 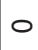 \\
\hline$\underset{\sim}{\sim}$ & 0 & 0 & 0 & 0 & $\rightarrow$ & 0 & -1 & $\checkmark$ & 0 & $r$ & 0 & 0 & 0 & 0 & 0 & 0 & 0 & 0 & 0 & 0 & \\
\hline 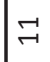 & 0 & $r$ & c & $\rightarrow$ & c & 10 & & 0 & $-r$ & 0 & 0 & $\sim$ & 0 & 0 & $\sim$ & 0 & 0 & 0 & 10 & 0 & \\
\hline \% & 6 & $m$ & 0 & 0 & 0 & 0 & 0 & 0 & $\sim$ & -1 & 0 & -1 & 0 & 0 & 0 & 0 & 0 & $\sim$ & $\sim$ & 0 & 0 \\
\hline 10 & 15 & 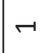 & 0 & 0 & 0 & & & o & $\mid 7$ & c & c & n & 0 & 0 & 0 & 0 & $\rightarrow$ & $\rightarrow$ & $\exists$ & $\neg$ & $\sigma_{0}$ \\
\hline$\infty$ & P & 0 & 0 & 0 & 10 & 0 & 0 & 0 & 0 & 0 & 10 & 0 & 0 & 0 & 0 & 0 & $\neg$ & 0 & $\checkmark$ & 0 & 0 \\
\hline$r$ & م & $\sim$ & 0 & 0 & 0 & 0 & 0 & 0 & 0 & 0 & 0 & $\sim$ & 0 & 0 & 0 & $\sim$ & $\sim$ & 0 & $\stackrel{\sim}{\sim}$ & $\vec{m}$ & 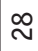 \\
\hline 0 & م & م & 0 & 0 & 0 & & & 0 & -1 & -1 & 0 & $r$ & 0 & 0 & 0 & $m$ & \& & $\cong$ & $\rightarrow$ & 0 & 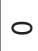 \\
\hline م & م & $m$ & c & $\stackrel{\infty}{\sim}$ & 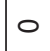 & 0 & 0 & D & 0 & F & $\stackrel{m}{m}$ & i & $\mathscr{\sim}$ & $\mathscr{\sim}$ & 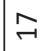 & $\stackrel{\square}{\sim}$ & 0 & 0 & 0 & 0 & c \\
\hline$\checkmark$ & $\mid 4$ & $\checkmark$ & $c$ & 0 & 0 & c & & $c$ & $\stackrel{\alpha}{\infty}$ & -1 & $c$ & $-r$ & 0 & 0 & $m$ & 0 & $\exists$ & $m$ & $\rightarrow$ & 0 & . \\
\hline$m$ & 0 & $m$ & 0 & $\hat{m}$ & $\approx$ & ণ & & & 0 & $\approx$ & \& & $\sim$ & 0 & 0 & $\neg$ & $r$ & 0 & 0 & o & 0 & $c$ \\
\hline$\sim$ & 0 & $\tilde{m}$ & 7 & $m$ & 0 & 0 & 0 & 0 & -1 & $-r \mid$ & 0 & $r$ & 0 & 0 & 0 & 0 & $\rightarrow$ & $\checkmark$ & $\rightarrow$ & 0 & $c$ \\
\hline- & $n$ & $\sim$ & 0 & r & $\sim$ & 0 & 0 & 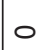 & 0 & -1 & 0 & $\sim$ & 0 & 0 & 0 & $-r$ & 0 & $-r$ & 0 & 0 & $c$ \\
\hline & 호 & 웅 & ָิ & $\begin{array}{l}\dot{8} \\
\dot{0}\end{array}$ & $\begin{array}{l}\text { ठे } \\
0 \\
0\end{array}$ & 8 & 0 & 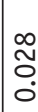 & $\delta$ & 8 & ৪ & চㅇ & రิ & ஜे & 号 & $\begin{array}{l}\tilde{N} \\
0 \\
0\end{array}$ & $\begin{array}{l}\dot{\delta} \\
\dot{0} \\
\dot{v}\end{array}$ & 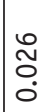 & $\begin{array}{l}\dot{\delta} \\
\dot{0} \\
\dot{v}\end{array}$ & $\begin{array}{l}\dot{8} \\
\dot{0}\end{array}$ & \\
\hline
\end{tabular}

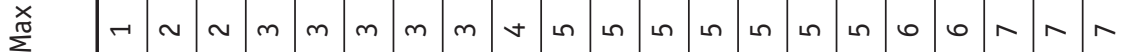




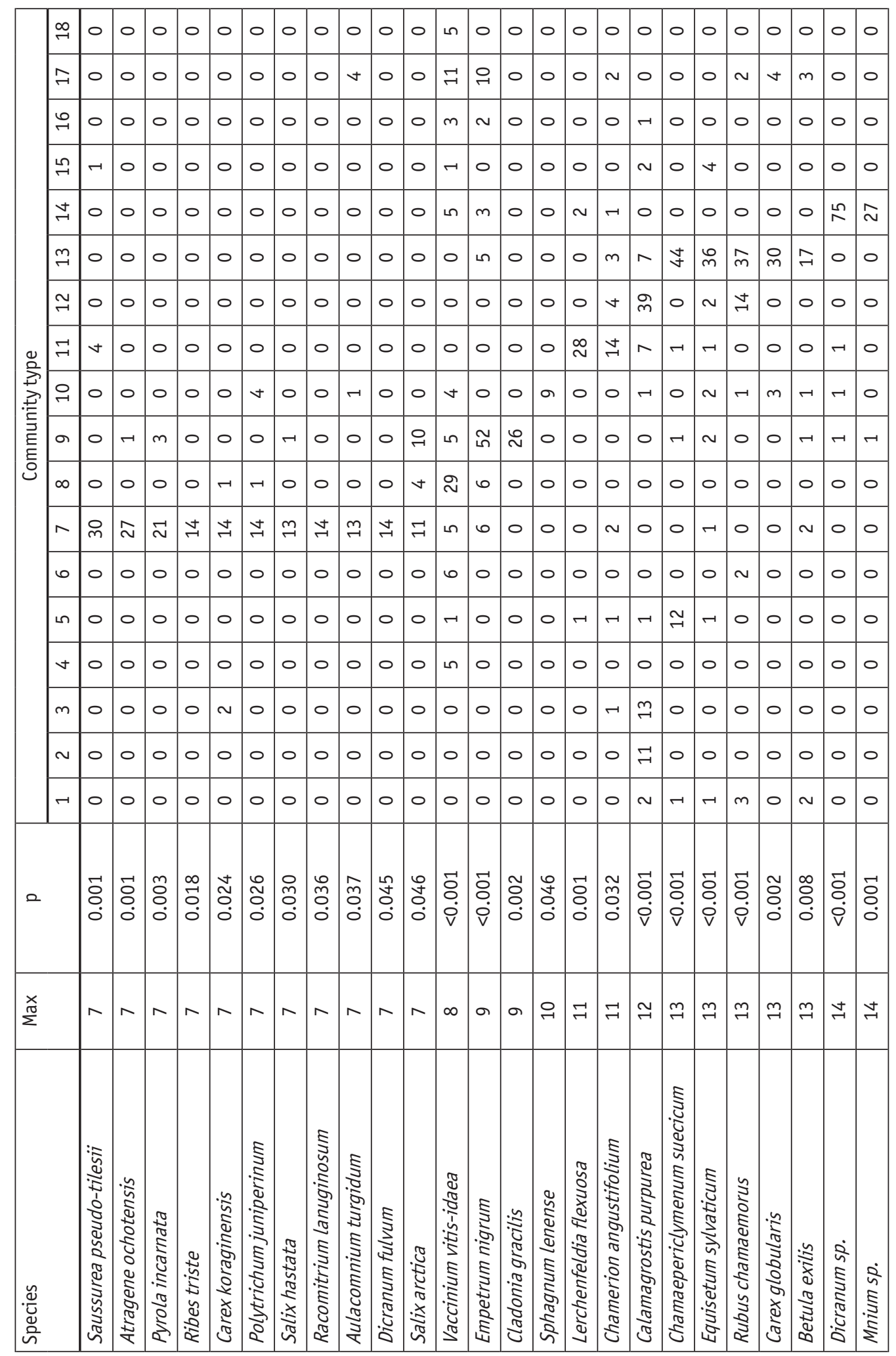




\begin{tabular}{|c|c|c|c|c|c|c|c|c|c|c|c|c|c|c|c|c|c|c|c|c|c|c|c|c|}
\hline$\left.\right|_{-1} ^{\infty}$ & $\neg$ & 0 & 0 & 0 & 0 & 0 & 0 & 0 & 0 & $\vec{F}$ & 0 & 0 & 0 & $\rightarrow$ & $\vec{v}$ & in & $\begin{array}{l}0 \\
⿱ \\
\forall\end{array}$ & $\approx$ & $\stackrel{\curvearrowleft}{\sim}$ & $\approx$ & $\vec{\sim}$ & $\stackrel{\bullet}{\sim}$ & $\underset{-1}{0}$ & $\vec{\neg}$ \\
\hline न & $\neg$ & $\rightarrow$ & 0 & 0 & 0 & 0 & 0 & 0 & 0 & $\stackrel{0}{\sim}$ & 0 & $\checkmark$ & 0 & $\stackrel{\bullet}{\sim}$ & -1 & -1 & 0 & 0 & 0 & 0 & 0 & 0 & $\rightarrow$ & 0 \\
\hline$\underset{-1}{0}$ & 0 & 0 & $\stackrel{m}{m}$ & $m$ & $m$ & $\infty$ & $m$ & $\stackrel{ \pm}{\sim}$ & $\stackrel{\cap}{\sim}$ & $\stackrel{\leftrightarrow}{\rightarrow}$ & $\hat{\neg}$ & $\stackrel{m}{\sim}$ & 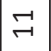 & $\checkmark$ & 0 & 0 & 0 & 0 & 0 & 0 & 0 & 0 & 0 & 0 \\
\hline$\stackrel{\text { I }}{\sim}$ & 0 & $\stackrel{\Omega}{\sim}$ & 0 & 0 & 0 & 0 & 0 & 0 & 0 & $r$ & 0 & 0 & 0 & $\checkmark$ & 0 & 0 & 0 & 0 & 0 & 0 & 0 & 0 & $m$ & 0 \\
\hline$\stackrel{\checkmark}{\sim}$ & $\stackrel{\infty}{\sim}$ & 0 & 0 & 0 & 0 & 0 & 0 & 0 & 0 & $\checkmark$ & 0 & $\neg$ & 0 & 0 & $\rightarrow$ & 0 & 0 & 0 & 0 & 0 & 0 & 0 & $m$ & 0 \\
\hline$\stackrel{m}{\rightarrow}$ & 0 & 0 & 0 & 0 & 0 & 0 & 0 & 0 & 0 & 0 & 0 & 0 & 0 & $\rightarrow$ & 0 & 0 & 0 & 0 & 0 & 0 & 0 & 0 & 0 & 0 \\
\hline$\approx$ & 0 & 0 & 0 & 0 & 0 & 0 & 0 & 0 & 0 & 0 & 0 & 0 & 0 & 0 & 0 & 0 & 0 & 0 & 0 & 0 & 0 & 0 & 0 & 0 \\
\hline ㄱ & 0 & 0 & 0 & 0 & 0 & 0 & 0 & 0 & 0 & 0 & 0 & 0 & $\rightarrow$ & $m$ & $\rightarrow$ & $\rightarrow$ & 0 & 0 & in & 0 & 0 & 0 & 0 & 0 \\
\hline 욱 & 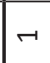 & 0 & $r$ & 0 & 0 & 10 & 10 & 10 & 0 & r & 0 & 0 & 0 & $\stackrel{\bullet}{\sim}$ & $\sim$ & -1 & 0 & 0 & 0 & 0 & 0 & 0 & 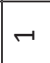 & 0 \\
\hline$a$ & 0 & 0 & $\checkmark$ & 0 & 0 & 0 & 0 & 0 & 0 & in & 0 & 0 & 0 & $m$ & $m$ & $m$ & 0 & 0 & 0 & $\rightarrow$ & $\sim$ & 0 & $\infty$ & 0 \\
\hline$\infty$ & $\sim$ & 0 & 0 & 0 & 0 & 0 & 0 & 0 & 0 & $\neg$ & 0 & $r$ & $m$ & 0 & $m$ & $\rightarrow$ & 0 & $\sim$ & 0 & 0 & 0 & $r$ & 0 & 0 \\
\hline 1 & 0 & 0 & 0 & 0 & 0 & 0 & 0 & 0 & 0 & $a$ & 0 & 0 & 0 & $\rightarrow$ & $\sim$ & 0 & 0 & 0 & 0 & 0 & 0 & $\sim$ & $\rightarrow$ & $\checkmark$ \\
\hline 0 & 0 & 0 & 0 & 0 & 0 & 0 & 0 & 0 & 0 & $\sim$ & 0 & 0 & $m$ & ـ & $\rightarrow$ & $\rightarrow$ & 0 & 0 & 0 & $\rightarrow$ & 0 & $\sim$ & 0 & 0 \\
\hline in & 0 & 0 & 0 & 0 & 0 & 0 & 0 & 0 & 0 & 0 & 0 & 0 & 0 & 우 & 0 & 0 & 0 & 0 & 0 & 0 & 0 & 0 & 0 & 0 \\
\hline$\checkmark$ & 0 & $\infty$ & 0 & 0 & 0 & $\neg$ & 0 & 0 & 0 & $\sim$ & 0 & 0 & 0 & $r$ & 0 & 0 & 0 & 0 & 0 & 0 & 0 & 0 & 0 & 0 \\
\hline$m$ & 0 & 0 & 0 & 0 & 0 & 0 & 0 & 0 & 0 & 0 & 0 & 0 & 0 & 0 & 0 & 0 & 0 & 0 & 0 & 0 & 0 & 0 & 0 & 0 \\
\hline$\sim$ & 0 & 0 & 0 & 0 & 0 & 0 & 0 & 0 & 0 & 0 & 0 & 0 & 0 & $\sim$ & 0 & $\rightarrow$ & $\rightarrow$ & 0 & 0 & 0 & 0 & 0 & 0 & 0 \\
\hline$\rightarrow$ & 0 & $\rightarrow$ & 0 & 0 & 0 & 0 & 0 & 0 & 0 & 0 & 0 & 0 & 0 & 0 & 0 & 0 & 0 & 0 & 0 & 0 & 0 & 0 & 0 & 0 \\
\hline & mo & $\begin{array}{l}\vec{a} \\
0 \\
0\end{array}$ & $\begin{array}{l}\text { ¿े } \\
\dot{0} \\
\dot{v}\end{array}$ & $\begin{array}{l}\overrightarrow{8} \\
\dot{0} \\
\dot{v}\end{array}$ & $\begin{array}{l}\overrightarrow{8} \\
\dot{0} \\
\dot{v}\end{array}$ & $\begin{array}{l}\dot{\delta} \\
\dot{0} \\
\dot{v}\end{array}$ & $\begin{array}{l}\vec{\delta} \\
\dot{8} \\
\dot{v}\end{array}$ & 客 & $\begin{array}{l}\tilde{\delta} \\
\text { Oे }\end{array}$ & 号 & Oे & $\mid \begin{array}{l}0 \\
0 \\
0 \\
0\end{array}$ & 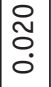 & $\begin{array}{l}\vec{b} \\
\dot{0} \\
\dot{v}\end{array}$ & $\begin{array}{l}\vec{b} \\
0 \\
\dot{v}\end{array}$ & $\mid \begin{array}{l}0 \\
\dot{0} \\
\dot{v}\end{array}$ & $\begin{array}{l}\vec{\delta} \\
\dot{0} \\
\dot{v}\end{array}$ & $\begin{array}{l}-\overrightarrow{0} \\
0 \\
0\end{array}$ & $\begin{array}{l}-1 \\
0 \\
0\end{array}$ & \begin{tabular}{l}
\multirow{2}{*}{} \\
0 \\
0
\end{tabular} & $\begin{array}{l}0 \\
0 \\
0 \\
0\end{array}$ & & & 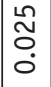 \\
\hline
\end{tabular}

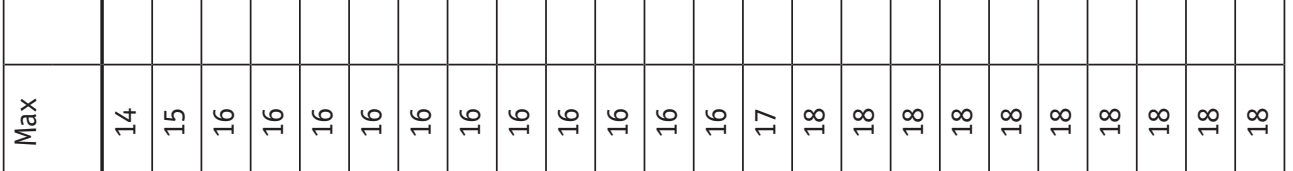

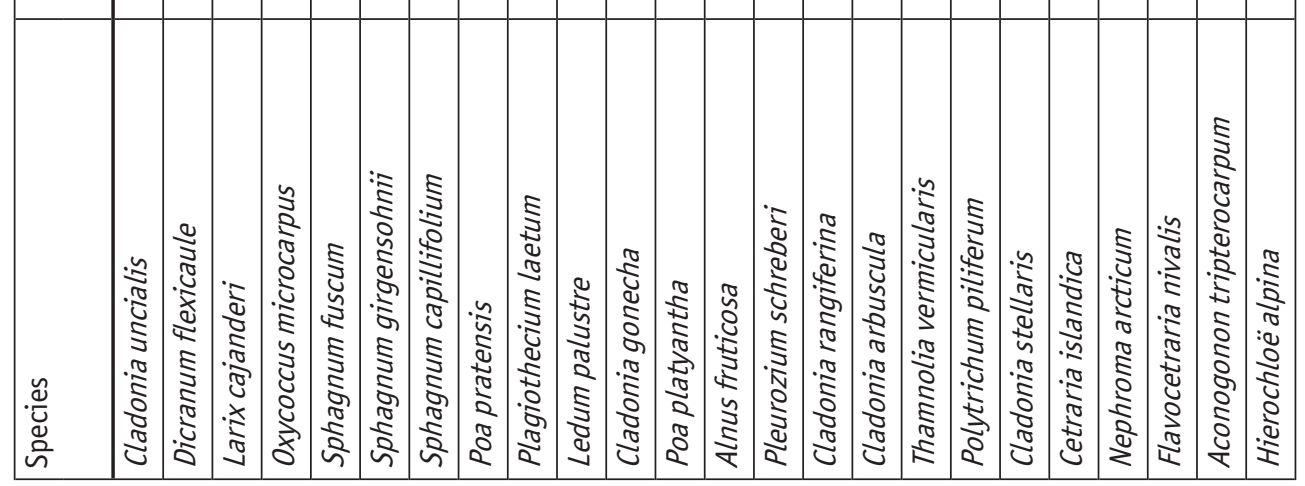

